\title{
Current status of African swine fever
}

\author{
Mary Louise Penrith* ${ }^{*}$
}

\begin{abstract}
African swine fever is a serious viral disease of domestic pigs and Eurasian wild boars that poses a major threat to pig production. For more than thirty years after its discovery in East Africa it was limited to eastern and southern Africa, where it is believed to have originated. The ability of the causative virus to remain viable for long periods in raw or insufficiently cooked pork products has enabled it, through travel and trade, to spread widely throughout subSaharan Africa and to other continents. In the second half of the $20^{\text {th }}$ century it had caused outbreaks in the majority of African countries where pigs are produced, as well as in a number of European countries, two of the Caribbean islands, and Brazil. By the turn of the century it had been eradicated from all non-African countries except the Italian island of Sardinia. In 2007 African swine fever arrived in the Republic of Georgia, and has subsequently spread insidiously into other Transcaucasian countries, Russia and some of its neighbours. In 2014 it reached the Baltic States and Poland through infected wild boars, and has become established in several wild boar populations from which it is difficult to eradicate. Most recently, in 2018 the first outbreaks were reported in China, home to half of the world's pig population, where it spread with unprecedented rapidity throughout China and to several other countries in the region, including the island nations of Philippines, Indonesia, Timor-Leste and Papua New Guinea. These events have posed new challenges for control, including some that parallel the situation in Africa, where poor people rely on pigs produced at subsistence level to provide for their needs and where pigs may also be socially and culturally important. The central role that humans play in the maintenance and spread of African swine fever has again been emphasised. This review describes the current status of African swine fever globally and the trends and challenges for management that face veterinarians and pig industries at all levels worldwide.
\end{abstract}

Keywords: African swine fever, Global spread, Domestic pigs, Wild boars

\section{Background}

African swine fever (ASF) is a lethal disease of domestic pigs and Eurasian wild boars caused by a unique DNA virus (Asfarviridae: Asfivirus). It is the only member of its family and the only known DNA arbovirus. It is maintained in a sylvatic cycle between common warthogs (Phacochoerus africanus) and soft ticks, also known as eyeless tampans, of the Ornithodoros moubata complex that inhabit their burrows in a large part of eastern and southern Africa (Mulumba-Mfumu et al. 2019; SánchezVizcaíno et al. 2015). The existence of this cycle and the large number of $\mathrm{p} 72$ genotypes that are found in this area

\footnotetext{
*Correspondence: marylouise@vodamail.co.za
}

Department of Veterinary Tropical Diseases, Faculty of Veterinary Science,

University of Pretoria, Old Soutpan Road, Onderstepoort, South Africa indicate that it is the most likely area of origin of ASF from which it has subsequently spread to other parts of the African continent and the world (Michaud et al. 2013). In the absence of the classic sylvatic cycle, ASF may be maintained in a domestic pig-tick cycle involving pig-associated species of Ornithodoros or in domestic pig populations that may be extended by non-captive Sus scrofa (feral pigs or Eurasian wild boars) (Fig. 1). With an official report of confirmed ASF in Papua New Guinea submitted to the World Organisation for Animal Health (OIE) on 30 March 2020 (Table 4), the disease is now present in all of the main regions of the world exception the Americas. The situation is highly concerning for the pig industry worldwide. In spite of ongoing and promising efforts to develop a vaccine, the current status of ASF in

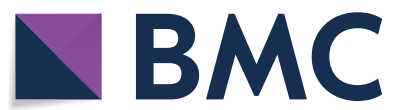

(c) The Author(s) 2020. This article is licensed under a Creative Commons Attribution 4.0 International License, which permits use, sharing, adaptation, distribution and reproduction in any medium or format, as long as you give appropriate credit to the original author(s) and the source, provide a link to the Creative Commons licence, and indicate if changes were made. The images or other third party material in this article are included in the article's Creative Commons licence, unless indicated otherwise in a credit line to the material. If material is not included in the article's Creative Commons licence and your intended use is not permitted by statutory regulation or exceeds the permitted use, you will need to obtain permission directly from the copyright holder. To view a copy of this licence, visit http://creativeco mmons.org/licenses/by/4.0/. The Creative Commons Public Domain Dedication waiver (http://creativecommons.org/publicdomain/ zero/1.0/) applies to the data made available in this article, unless otherwise stated in a credit line to the data. 


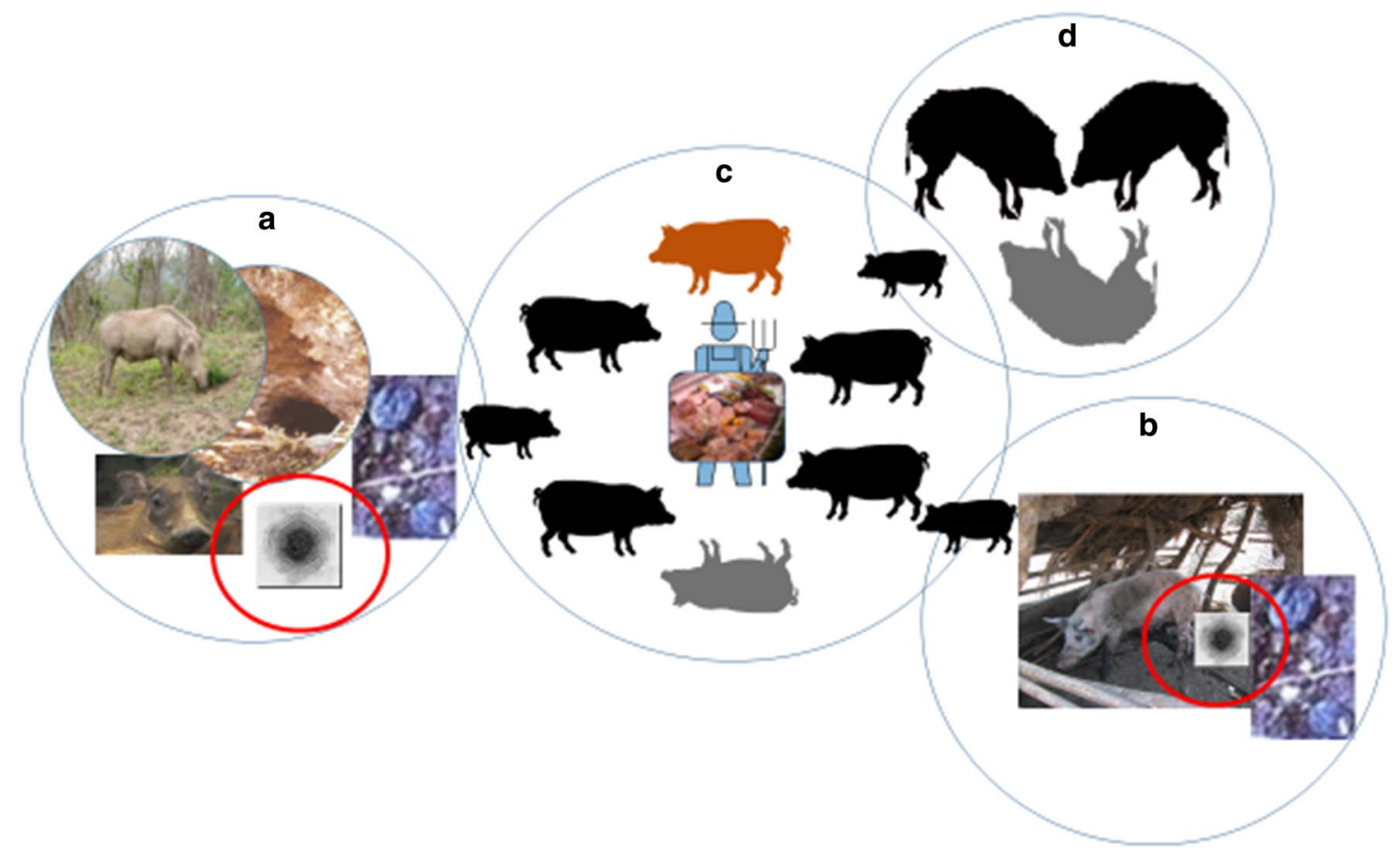

Fig. 1 Cycles in which ASF virus is maintained. a Warthog-tick cycle, Eastern and Southern Africa (genotypes I-XXII, XXIV); b Domestic pig-tick cycle, Eastern and Southern Africa (genotypes VIII, XXIV) and historical in Iberian Peninsula (genotype I); c Domestic pig cycle (genotypes I-X, XII, XIV-XXIV in the area with the classic sylvatic cycle; genotypes I or II elsewhere); $\mathbf{d}$ Wild boar-environment cycle, Europe (genotype II)

terms of management tools is that there is no vaccine and no treatment.

The first description of ASF was published in 1921 (Montgomery 1921), based on outbreaks of a fatal haemorrhagic disease that had been reported mainly in Kenya since 1914 in the pigs of European settlers. Outbreaks of a similar disease had also been registered in the Eastern Province of Zambia since 1912 (Wilkinson et al. 1988). Reports of suspected 'East African swine fever' in the north-eastern part of South Africa were published in 1928 (Steyn 1928; 1932), followed by Angola (Gago da Câmara 1932; Mendes 1994) and Malawi (Turnbull 1931, 1932, 1934), and by the 1950s the disease was known to exist in most countries in eastern and southern Africa and the southern parts of Central Africa (Plowright et al. 1994). The disease apparently remained restricted to this region until the late 1950s, when incursions occurred into both Europe and West Africa, initiating the first international events in the history of ASF. The historical and present status of ASF worldwide is reflected in Table 1. A timeline showing the progression of ASF over time in Africa, historically in Europe and the American region, and in Europe, Asia and Oceania since 2007 is provided in Fig. 2.

In the first excursion outside Africa, an outbreak of ASF occurred close to the airport in Lisbon, Portugal, in 1957 (Vigário et al. 1983), believed to have originated in Angola (Bastos et al. 2003). The first outbreak in West Africa was reported from Dakar, Senegal, in 1959 (Bastos et al. 2003), with anecdotal reports of outbreaks in Guinea Bissau and the island nation of Cape Verde as well (Brown et al. 2018). The outbreak in Portugal was promptly eradicated but in 1960 another incursion into Portugal occurred, with rapid spread to Spain, initiating a presence in the Iberian Peninsula that lasted for more than 30 years. During that period the virus demonstrated its potential for long-distance spread as outbreaks occurred in Belgium, France, Italy, Malta and The Netherlands in western Europe and Cuba, Dominican Republic and Haiti, and Brazil (Cwynar et al. 2019) (Table 1). The disease remains endemic in Sardinia, Italy since its introduction in 1978 (Laddomada et al. 2019). Russia experienced outbreaks in the Odessa region (now in Ukraine) in 1977 (Korennoy et al. 2017).

The next escape from Africa occurred in 2007 with the introduction of ASF into the Republic of Georgia, with rapid spread to other Transcaucasian countries (Armenia, Azerbaijan, Russia [Chechnya]) as well as further northwards into Russia (Gogin et al. 2013) and south into Iran, affecting only wild boars as there are no domestic pigs (Rahimi et al. 2010). Since 2011 ASF has infected an impressive number of countries in Europe and Asia as well as sub-Saharan Africa (Table 1). 
Table 1 Historic and current status, all countries that have reported ASF

\begin{tabular}{|c|c|c|c|c|}
\hline Country & ASF known presence & Species confirmed ${ }^{a}$ & Current status & Relevant references \\
\hline \multicolumn{5}{|l|}{ African region } \\
\hline \multicolumn{5}{|c|}{ Sub-region: Eastern, Central and Southern Africa } \\
\hline \multicolumn{5}{|l|}{ Present } \\
\hline Angola & 1932 to present & Domestic pigs & Endemic & (Gago da Câmara 1932) \\
\hline Botswana & 1979 to present & Warthogs; rarely pigs & Endemic in warthogs & (Simpson and Drager 1979) \\
\hline Burundi & Isolates 1984, 1990 & Domestic pigs & Endemic & $\begin{array}{l}\text { (Disease information-Immediate } \\
\text { notifications 2005-2020; Lubisi } \\
\text { et al. 2005; Phologane et al. 2005) }\end{array}$ \\
\hline Cameroon & 1982 to present & Domestic pigs & Endemic & $\begin{array}{l}\text { (Ekue and Wilkinson 1990; Nana- } \\
\text { Nukechap and Gibbs 1985) }\end{array}$ \\
\hline Central African Republic & 2010 to present & Domestic pigs & Endemic & $\begin{array}{l}\text { (Disease information-Immediate } \\
\text { notifications 2005-2020) }\end{array}$ \\
\hline Chad & 2010 to present & Domestic pigs & Endemic & $\begin{array}{l}\text { (Disease information-Immediate } \\
\text { notifications 2005-2020; Bidjeh } \\
\text { et al. 2015) }\end{array}$ \\
\hline Congo (Brazzaville) & Before 1975 to present & Domestic pigs, warthogs ${ }^{b}$ & Endemic & $\begin{array}{l}\text { (Plowright et al. 1994; Badaev et al. } \\
\text { 1992) }\end{array}$ \\
\hline Congo (DRC) & 1939 to present & Domestic pigs & Endemic & $\begin{array}{l}\text { (Bisimwa et al. 2019; Saliki et al. } \\
\text { 1985) }\end{array}$ \\
\hline Ethiopia & $2011-2014$ & Domestic pigs & Unknown & (Achenbach et al. 2017) \\
\hline Kenya & 1914 to present & Warthogs, pigs & Endemic & $\begin{array}{l}\text { (Montgomery 1921; Abworo et al. } \\
\text { 2017; Thomas et al. 2016) }\end{array}$ \\
\hline Madagascar & 1998 to present & Domestic pigs & Endemic & $\begin{array}{l}\text { (Rousset et al. 2001; Roger et al. } \\
\text { 2000) }\end{array}$ \\
\hline Malawi & 1932 to present & Domestic pigs, warthogs & Endemic & $\begin{array}{l}\text { (Turnbull 1931, 1932, 1934; } \\
\text { Haresnape et al. 1988) }\end{array}$ \\
\hline Mozambique & 1954 & Warthogs, pigs & Endemic & $\begin{array}{l}\text { (Quembo et al. 2016; de Abreu et al. } \\
\text { 1962; Penrith et al. 2007) }\end{array}$ \\
\hline Namibia & $1920 s$ & Warthogs, pigs & Endemic in warthogs & (Plowright et al. 1994) \\
\hline South Africa & 1926 to present & Warthogs, pigs & Endemic in warthogs & (Steyn 1928; De Kock et al. 1940) \\
\hline Rwanda & 482 outbreak reports & Domestic pigs & Endemic & $\begin{array}{l}\text { (Disease information-Immediate } \\
\text { notifications 2005-2020; Bisimwa } \\
\text { et al. 2019) }\end{array}$ \\
\hline Tanzania & 1914 to present & Warthogs, pigs & Endemic & $\begin{array}{l}\text { (Montgomery 1921; Chang'a et al. } \\
\text { 2019; Katale et al. 2012) }\end{array}$ \\
\hline Uganda & 1983 to present & Warthogs, pigs & Endemic & $\begin{array}{l}\text { (Plowright et al. 1994; Atuhaire et al. } \\
\text { 2013) }\end{array}$ \\
\hline Zambia & 1912 to present & Warthogs, pigs & Endemic & (Wilkinson et al. 1988) \\
\hline Zimbabwe & 1970s to present & Warthogs, pigs & Endemic in warthogs & (Plowright et al. 1994) \\
\hline \multicolumn{5}{|l|}{ Historic } \\
\hline Mauritius & $2007-2008$ & Domestic pigs & Free (SD 2012) & (Lubisi et al. 2009) \\
\hline São Tomé e Principe & 1979-1980; 1992 & Domestic pigs & Free & $\begin{array}{l}\text { (Sánchez-Botija 1982; Wesley and } \\
\text { Tuthill 1984) }\end{array}$ \\
\hline \multicolumn{5}{|l|}{ West Africa } \\
\hline Benin & 1997 to present & Domestic pigs & Endemic & $\begin{array}{l}\text { (Disease information-Immediate } \\
\text { notifications 2005-2020; Brown } \\
\text { et al. 2018) }\end{array}$ \\
\hline Burkina Faso & 2002 to present & Domestic pigs & Endemic & $\begin{array}{l}\text { (Disease information-Immediate } \\
\text { notifications 2005-2020; Brown } \\
\text { et al. 2018) }\end{array}$ \\
\hline Cape Verde & ca 1959 to present & Domestic pigs & Uncertain & $\begin{array}{l}\text { (Disease information-Immediate } \\
\text { notifications 2005-2020; Brown } \\
\text { et al. 2018) }\end{array}$ \\
\hline
\end{tabular}


Table 1 (continued)

\begin{tabular}{|c|c|c|c|c|}
\hline Country & ASF known presence & Species confirmed ${ }^{a}$ & Current status & Relevant references \\
\hline Côte d'Ivoire & 1996, 2014, 2018,2019 & Domestic pigs & Free with sporadic incursions & $\begin{array}{l}\text { (Disease information-Immediate } \\
\text { notifications 2005-2020; Brown } \\
\text { et al. 2018; Couacy-Hymann et al. } \\
\text { 2019) }\end{array}$ \\
\hline Gambia (The) & 1997,2000 & Domestic pigs & Uncertain (no reports) & (Brown et al. 2018) \\
\hline Ghana & 1999; 2002 to present & Domestic pigs & Endemic & $\begin{array}{l}\text { (Disease information-Immediate } \\
\text { notifications 2005-2020; Brown } \\
\text { et al. 2018) }\end{array}$ \\
\hline Guinea Bissau & ca. 1959 to present & Domestic pigs & Endemic & $\begin{array}{l}\text { (Disease information-Immediate } \\
\text { notifications 2005-2020; Brown } \\
\text { et al. 2018) }\end{array}$ \\
\hline Liberia & 2011 (AU-IBAR) & Domestic pigs & Unknown & $\begin{array}{l}\text { (Panafrican Animal Health Yearbook } \\
\text { 2011) }\end{array}$ \\
\hline Mali & 2016 & Domestic pigs & Free & $\begin{array}{l}\text { (Disease information-Immediate } \\
\text { notifications 2005-2020) }\end{array}$ \\
\hline Nigeria & $1973 ; 1997$ to present & Domestic pigs & Endemic & $\begin{array}{l}\text { (Disease information-Immediate } \\
\text { notifications 2005-2020; Brown } \\
\text { et al. 2018) }\end{array}$ \\
\hline Senegal & 1959 to present & Domestic pigs & Endemic & $\begin{array}{l}\text { (Disease information-Immediate } \\
\text { notifications 2005-2020; Etter } \\
\text { et al. 2011) }\end{array}$ \\
\hline Sierra Leone & 2019 & Domestic pigs & Uncertain & $\begin{array}{l}\text { (Disease information-Immedi- } \\
\text { ate notifications 2005-2020; } \\
\text { Wadoum et al. 2020) }\end{array}$ \\
\hline Togo & 1997 to present & Domestic pigs & Endemic & $\begin{array}{l}\text { (Disease information-Immediate } \\
\text { notifications 2005-2020; Brown } \\
\text { et al. 2018) }\end{array}$ \\
\hline \multicolumn{5}{|c|}{ Caribbean and South America-historic } \\
\hline Brazil & 1978-1981 & Domestic pigs & Free & (Moura et al. 1978) \\
\hline Cuba & $1971 ; 1981$ & Domestic pigs & Free & (Negrin 1980) \\
\hline Dominican Republic & 1978-1980 & Domestic pigs & Free & (Rivera 1983) \\
\hline Haiti & 1978-1984 & Domestic pigs & Free & (Alexander 1992) \\
\hline \multicolumn{5}{|c|}{ Europe and Transcaucasus } \\
\hline \multicolumn{5}{|c|}{ Present/recent } \\
\hline Armenia & $2007-2014$ & Domestic pigs, wild boars & $\begin{array}{l}\text { Last outbreak in pigs confirmed } \\
\text { in } 2014\end{array}$ & $\begin{array}{l}\text { (Disease information-Immediate } \\
\text { notifications 2005-2020) }\end{array}$ \\
\hline Azerbaijan & 2008 & Domestic pigs & Free (SD 2011) & $\begin{array}{l}\text { (Disease information-Immediate } \\
\text { notifications 2005-2020) }\end{array}$ \\
\hline Belarus & 2013 & Domestic pigs & Uncertain & $\begin{array}{l}\text { (Disease information-Immediate } \\
\text { notifications 2005-2020) }\end{array}$ \\
\hline Belgium & 2018-2019 & Wild boars & Not yet officially eradicated & $\begin{array}{l}\text { (Disease information-Immediate } \\
\text { notifications 2005-2020; Linden } \\
\text { et al. 2018) }\end{array}$ \\
\hline Bulgaria & $2018-2020$ & Domestic pigs, wild boars & Not yet eradicated & $\begin{array}{l}\text { (Disease information-Immediate } \\
\text { notifications 2005-2020; Zani } \\
\text { et al. 2019) }\end{array}$ \\
\hline Czech Republic & $2017-2018$ & Wild boars & Free (SD 2019) & $\begin{array}{l}\text { (Disease information-Immediate } \\
\text { notifications 2005-2020; Marcon } \\
\text { et al. 2020) }\end{array}$ \\
\hline Estonia & 2014 to present & Wild boars, domestic pigs & $\begin{array}{l}\text { Free in domestic and captive wild } \\
\text { pigs (SD 2018); declining in wild } \\
\text { boars }\end{array}$ & $\begin{array}{l}\text { (Nurmoja et al. 2018; Schulz et al. } \\
\text { 2019; Nurmoja et al. 2017) }\end{array}$ \\
\hline Georgia & $2007,2010,2011$ & Domestic pigs & Uncertain & (Vepkhvadze et al. 2017) \\
\hline Greece & 2019 & Domestic pigs & Uncertain & $\begin{array}{l}\text { (Disease information-Immediate } \\
\text { notifications 2005-2020) }\end{array}$ \\
\hline Hungary & $2018-2020$ & Wild boars & Uncertain & $\begin{array}{l}\text { (Disease information-Immediate } \\
\text { notifications 2005-2020) }\end{array}$ \\
\hline
\end{tabular}


Table 1 (continued)

\begin{tabular}{|c|c|c|c|c|}
\hline Country & ASF known presence & Species confirmed $^{a}$ & Current status & Relevant references \\
\hline Italy (Sardinia) & 1978 to present & Domestic pigs, wild boars & Endemic & $\begin{array}{l}\text { (Laddomada et al. 2019; Mur et al. } \\
\text { 2016; Contini et al. 1983) }\end{array}$ \\
\hline Latvia & 2014 to present & Wild boars, domestic pigs & $\begin{array}{c}\text { Possibly declining in wild boars; } \\
\text { last pig outbreak in mid-2019 }\end{array}$ & $\begin{array}{l}\text { (Disease information-Immediate } \\
\text { notifications 2005-2020; Olsevs- } \\
\text { kis et al. 2014) }\end{array}$ \\
\hline Lithuania & 2014 to present & Wild boars, domestic pigs & Endemic in wild boars & (Mačiulskis et al. 2020) \\
\hline Moldova & 2016 to present & Domestic pigs, wild boars & Infected & $\begin{array}{l}\text { (Disease information-Immediate } \\
\text { notifications 2005-2020) }\end{array}$ \\
\hline Poland & 2014 to present & Wild boars, domestic pigs & Endemic in wild boars & $\begin{array}{l}\text { (Disease information-Immediate } \\
\text { notifications 2005-2020; Cwynar } \\
\text { et al. 2019; Pejsak et al. 2014; } \\
\text { Pejsak et al. 2018) }\end{array}$ \\
\hline Romania & 2017 to present & Domestic pigs, wild boars & Infected & $\begin{array}{l}\text { (Disease information-Immediate } \\
\text { notifications 2005-2020; Cwynar } \\
\text { et al. 2019) }\end{array}$ \\
\hline Russia & 2007 to present & Domestic pigs, wild boars & Endemic & $\begin{array}{l}\text { (Disease information-Immediate } \\
\text { notifications 2005-2020; Gogin } \\
\text { et al. 2013) }\end{array}$ \\
\hline Serbia & 2019 to present & Domestic pigs, wild boars & Infected & $\begin{array}{l}\text { (Disease information-Immediate } \\
\text { notifications 2005-2020) }\end{array}$ \\
\hline Slovakia & 2019 to present & Domestic pigs, wild boars & Infected & $\begin{array}{l}\text { (Disease information-Immediate } \\
\text { notifications 2005-2020) }\end{array}$ \\
\hline Ukraine & 2012 to present & Domestic pigs, wild boars & Endemic & $\begin{array}{l}\text { (Disease information-Immediate } \\
\text { notifications 2005-2020) }\end{array}$ \\
\hline \multicolumn{5}{|l|}{ Historic } \\
\hline Belgium & 1985 & Domestic pigs & Free (SD 2008) & (Biront et al. 1987) \\
\hline France & $1964,1967,1977$ & Domestic pigs & Free (SD 2008) & (Costard et al. 2009) \\
\hline Italy & 1967,1980 & Domestic pigs & Free (SD 2008) & (Costard et al. 2009) \\
\hline Malta & 1978-1979 & Domestic pigs & Free & (Wilkinson et al. 1980) \\
\hline Netherlands (The) & 1986 & Domestic pigs & Free (SD 2008) & $\begin{array}{l}\text { (Cwynar et al. 2019; Terpstra and } \\
\text { Wensvoort 1986) }\end{array}$ \\
\hline Portugal & 1957; 1960-1993; 1999 & Domestic pigs, wild boars & Free (SD 2008) & $\begin{array}{l}\text { (Vigário et al. 1983; Boinas et al. } \\
\text { 2004; Madeira et al. 2015) }\end{array}$ \\
\hline Portugal (Madeira) & $1965,1974,1976$ & Domestic pigs & Free & (Plowright et al. 1994) \\
\hline Russia & $1977^{c}$ & Domestic pigs & Eradicated & (Korennoy et al. 2017) \\
\hline Spain & 1960-1994 & Domestic pigs, wild boars & Free (SD 2008) & $\begin{array}{l}\text { (Sánchez-Vizcaíno et al. 2015; } \\
\text { Sánchez-Botija 1982; Ordás et al. } \\
\text { 1983) }\end{array}$ \\
\hline \multicolumn{5}{|l|}{ Asia } \\
\hline Cambodia & 2019 to present & Domestic pigs & Infected & $\begin{array}{l}\text { (Disease information-Immediate } \\
\text { notifications 2005-2020) }\end{array}$ \\
\hline China (People's Republic) & 2018 to present & Domestic pigs, wild boars & Infected & $\begin{array}{l}\text { (Disease information-Immediate } \\
\text { notifications 2005-2020; Zhou } \\
\text { et al. 2018; Li et al. 2019; Li and } \\
\text { Tian 2018) }\end{array}$ \\
\hline China (Hong Kong) & 2019 & Domestic pigs & Uncertain $^{d}$ & $\begin{array}{l}\text { (Disease information-Immediate } \\
\text { notifications 2005-2020) }\end{array}$ \\
\hline India & 2020 & Domestic pigs & Infected & $\begin{array}{l}\text { (Disease information-Immediate } \\
\text { notifications 2005-2020) }\end{array}$ \\
\hline Indonesia & 2019 & Domestic pigs & Infected & $\begin{array}{l}\text { (Disease information-Immediate } \\
\text { notifications 2005-2020) }\end{array}$ \\
\hline Iran & $2008-2009$ & Wild boars & Free & (Rahimi et al. 2010) \\
\hline Korea (North) & 2019 & Domestic pigs & Infected & $\begin{array}{l}\text { (Disease information-Immediate } \\
\text { notifications 2005-2020) }\end{array}$ \\
\hline
\end{tabular}


Table 1 (continued)

\begin{tabular}{|c|c|c|c|c|}
\hline Country & ASF known presence & Species confirmed ${ }^{a}$ & Current status & Relevant references \\
\hline Korea (South & 2019 & Wild boars, domestic pigs & Infected & $\begin{array}{l}\text { (Disease information-Immediate } \\
\text { notifications 2005-2020; Kim et al. } \\
\text { 2020a; Jo and Gortázar 2020) }\end{array}$ \\
\hline Lao & 2019 & Domestic pigs & Infected & $\begin{array}{l}\text { (Disease information-Immediate } \\
\text { notifications 2005-2020) }\end{array}$ \\
\hline Mongolia & 2019, eradicated & Domestic pigs & Free & $\begin{array}{l}\text { (Disease information-Immediate } \\
\text { notifications 2005-2020; Heilmann } \\
\text { et al. 2020) }\end{array}$ \\
\hline Myanmar & 2019 to present & Domestic pigs & Infected & $\begin{array}{l}\text { (Disease information-Immediate } \\
\text { notifications 2005-2020) }\end{array}$ \\
\hline Philippines & 2019 to present & Domestic pigs & Infected & $\begin{array}{l}\text { (Disease information-Immediate } \\
\text { notifications 2005-2020) }\end{array}$ \\
\hline Timor Leste & 2019 & Domestic pigs & Infected & $\begin{array}{l}\text { (Disease information-Immediate } \\
\text { notifications 2005-2020; Smith } \\
\text { et al. 2019) }\end{array}$ \\
\hline Vietnam & 2019 & Domestic pigs & Infected & $\begin{array}{l}\text { (Disease information-Immediate } \\
\text { notifications 2005-2020) }\end{array}$ \\
\hline \multicolumn{5}{|l|}{ Oceania } \\
\hline Papua New Guinea & 2020 & Domestic pigs & Infected & $\begin{array}{l}\text { (Disease information-Immediate } \\
\text { notifications 2005-2020) }\end{array}$ \\
\hline
\end{tabular}

https://www.oie.int/fileadmin/Home/eng/Animal_Health_in_the_World/docs/pdf/Self-declarations/ENG_archive_2000_Feb_2020.pdf $S D$ self-declaration to OIE

a Note that African wild suids other than warthogs are not included, as there is relatively little information and a role in the epidemiology of ASF has not been demonstrated although, like warthogs, they are impervious to the pathogenic effects of ASF. They have no association with Ornithodoros ticks due to their habits and habitat, but a limited role for bushpigs may be possible

b Warthogs are now considered to be extinct in Congo People's Republic

c The outbreaks occurred in Odessa, now part of Ukraine

$d$ The outbreaks involved infected pig carcasses from mainland China for processing; there have been no outbreaks in pigs produced in Hong Kong

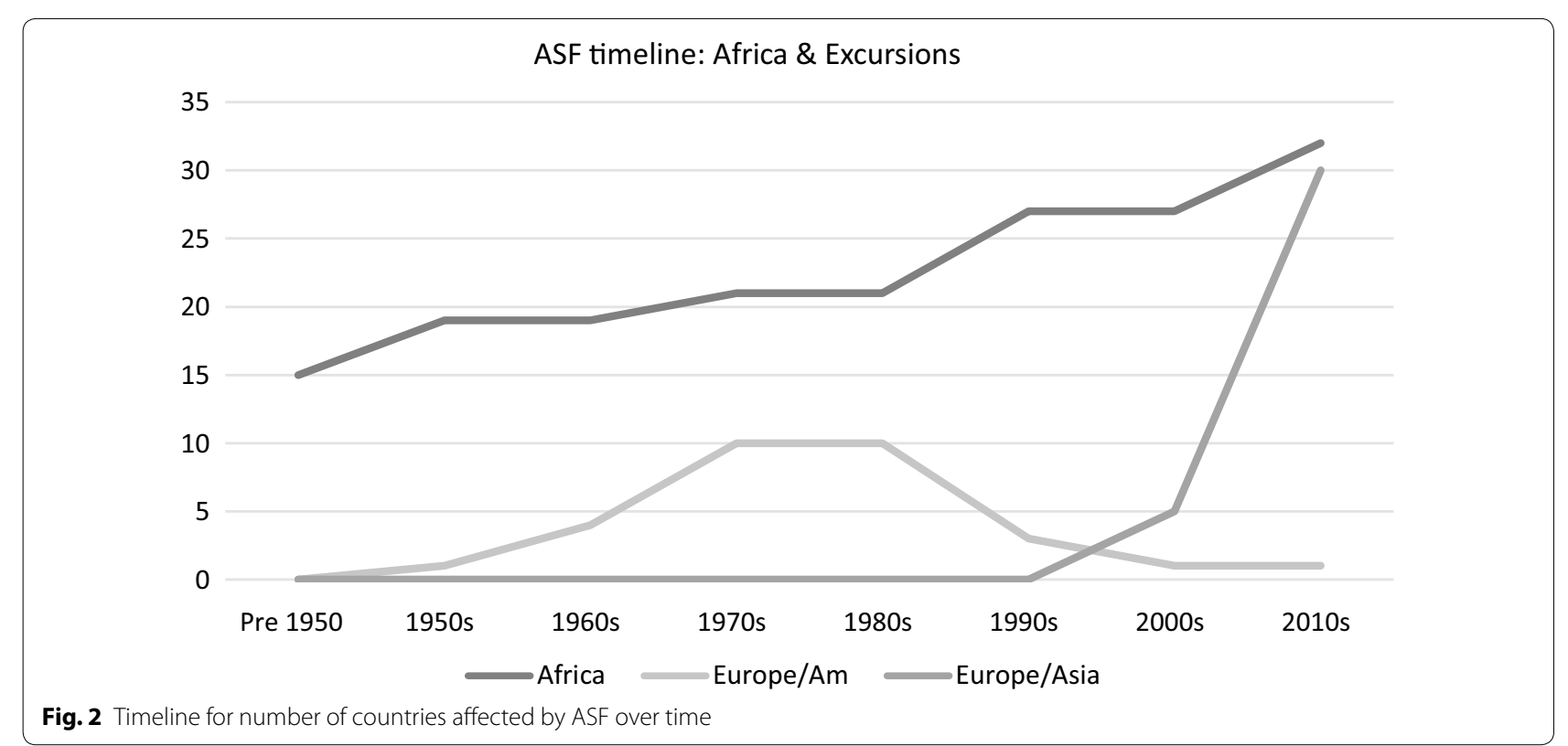

This review summarises the current status of ASF in these regions as reflected in the World Organisation for Animal Health (OIE) Information System (OIEWAHIS) database (Disease information-Immediate notifications 2005-2020), ProMED-mail, ${ }^{1}$ and relevant peer-reviewed publications. The links to relevant OIE

\footnotetext{
${ }^{1}$ The e-mail disease information system of the International Society for Infectious Diseases (http://www.isid.org).
} 
Table 2 Links to Immediate notifications to the World Organisation for Animal Health (OIE), 2007-2020: Africa

\begin{tabular}{|c|c|c|}
\hline Country & Report date & URL \\
\hline Sierra Leone & $11 / 02 / 2020$ & $\begin{array}{l}\text { https://www.oie.int/wahis_2/public/wahid.php/Reviewreport/Review?page_refer } \\
\text { =MapFullEventReport\&reportid=32924 }\end{array}$ \\
\hline \multirow[t]{2}{*}{ Namibia } & $15 / 04 / 2009$ & https://www.oie.int/wahis_2/public/wahid.php/Reviewreport/Review?reportid=8011 \\
\hline & $10 / 05 / 2009$ & https://www.oie.int/wahis_2/public/wahid.php/Reviewreport/Review?reportid=8088 \\
\hline Zimbabwe, Manicaland & $14 / 02 / 2019$ & https://www.oie.int/wahis_2/public/wahid.php/Reviewreport/Review?reportid=29531 \\
\hline \multirow{2}{*}{$\begin{array}{l}\text { Zimbabwe, Mashonaland } \\
\text { Central }\end{array}$} & 23/08/2019 & https://www.oie.int/wahis_2/public/wahid.php/Reviewreport/Review?reportid=31533 \\
\hline & 07/11/2019 & https://www.oie.int/wahis_2/public/wahid.php/Reviewreport/Review?reportid=32134 \\
\hline Mali & 01/01/2016 & https://www.oie.int/wahis_2/public/wahid.php/Reviewreport/Review?reportid=19778 \\
\hline Côte d'Ivoire, San Pedro & $27 / 08 / 2014$ & https://www.oie.int/wahis_2/public/wahid.php/Reviewreport/Review?reportid=15914 \\
\hline $\begin{array}{l}\text { Côte d'Ivoire, } \\
\text { Ferkessedougou,Korhogo }\end{array}$ & $\begin{array}{l}\text { 10/10/2017; } \\
\text { 17/04/2018; 06/07/2018 }\end{array}$ & $\begin{array}{l}\text { https://www.oie.int/wahis_2/public/wahid.php/Reviewreport/Review?reportid=24989 } \\
\text { https://www.oie.int/wahis_2/public/wahid.php/Reviewreport/Review?reportid=26359 } \\
\text { https://www.oie.int/wahis_2/public/wahid.php/Reviewreport/Review?reportid=27167 }\end{array}$ \\
\hline Côte d'Ivoire, Bangolo, Duekoue & $01 / 10 / 2019$ & $\begin{array}{l}\text { https://www.oie.int/wahis_2/public/wahid.php/Reviewreport/Review?page_refer } \\
\text { =MapFullEventReport\&reportid=31995 }\end{array}$ \\
\hline Cameroon, Extreme North & 05/2010 & $\begin{array}{l}\text { https://www.oie.int/wahis_2/public/wahid.php/Diseaseinformation/statusdetail/popup } \\
\text { ?diseaseid=12\&country=CMR\&y=2010\&m=5\&admin } 1=565 \& \text { detail=2\&sdid=430610 }\end{array}$ \\
\hline Chad, Mayo Kebi East & $22 / 10 / 2010$ & https://www.oie.int/wahis_2/public/wahid.php/Reviewreport/Review?reportid=9867 \\
\hline $\begin{array}{l}\text { Chad, Ndjamena, Mayo Kebi } \\
\text { East }\end{array}$ & 14/09/2018;04/02/2019 & $\begin{array}{l}\text { https://www.oie.int/wahis_2/public/wahid.php/Reviewreport/Review?reportid=27967 } \\
\text { https://www.oie.int/wahis_2/public/wahid.php/Reviewreport/Review?reportid=29244 }\end{array}$ \\
\hline \multirow[t]{3}{*}{ Central African Republic } & $11 / 12 / 2010$ & https://www.oie.int/wahis_2/public/wahid.php/Reviewreport/Review?reportid=10059 \\
\hline & $05 / 2012$ & $\begin{array}{l}\text { https://www.oie.int/wahis_2/public/wahid.php/Diseaseinformation/statusdetail/popup } \\
\text { ?diseaseid }=12 \& \text { country=CAF\&y }=2012 \& m=2 \& \text { admin } 1=632 \& d e t a i l=2 \& \text { sdid }=533459\end{array}$ \\
\hline & 07/12/2015 & $\begin{array}{l}\text { https://www.oie.int/wahis_2/public/wahid.php/Diseaseinformation/statusdetail/popup } \\
\text { ?diseaseid=12\&country=CAF\&y=2015\&m=7\&admin 1=619\&detail=3\&sdid=685423 }\end{array}$ \\
\hline
\end{tabular}

reports are provided in Tables 2, 3, 4 for ease of reference. The main trends and challenges in each region for prevention and control are identified and analysed based on the information presented. Details of how these challenges may be addressed are beyond the scope of this review, but commonalities exist in smallholder pig production and human behaviour across the regions. The challenge is to identify practical, sustainable farmer-based and situation-specific solutions and develop risk mitigation strategies along pig and pork value chains that will have positive outcomes for a sector with enormous potential for poverty reduction through production of high quality protein.

\section{Current status and trends of ASF and major challenges for management and eradication} Sub-Saharan Africa

Thirty-four countries in sub-Saharan Africa have experienced at least one confirmed ASF outbreak, the most recent one being Sierra Leone (Wadoum et al. 2020), (Table 2). In addition, the AU-IBAR yearbook for 2011 (Panafrican Animal Health Yearbook 2011) reported an outbreak in Liberia that is considered credible although no details of confirmation are available. Countries are considered to be endemically infected if outbreaks in domestic pigs have been reported to OIE on multiple occasions over a period of five or more years since 2005 and no self-declaration of freedom has been made or if the classic sylvatic cycle has been confirmed or is strongly suspected to be present.

The most important trends observed in sub-Saharan Africa in recent decades have been endemic establishment in most countries that have been recently infected; an increase in the number of countries infected or reinfected, and spread to previously free areas in countries where ASF is endemic. Poor reporting remains a challenge, as the ASF status of some countries is unknown.

\section{Endemic area with classic sylvatic cycle in eastern and southern Africa}

Infection in either warthogs or Ornithodoros ticks collected from their burrows or both has been demonstrated in Botswana (Simpson and Drager 1979), Kenya (Montgomery 1921), Malawi (Haresnape et al. 1988), Mozambique (Quembo et al. 2016; Quembo et al. 2018), Namibia, South Africa, Tanzania, Uganda, Zambia and Zimbabwe (Plowright et al. 1994). More than one p72 genotype has been reported from all of these countries. 
Table 3 Links to Immediate notifications to the World Organisation for Animal Health (OIE), 2007-2020: Transcaucasus and Europe

\begin{tabular}{|c|c|c|}
\hline Country & Report date & URL \\
\hline Georgia & 05/06/2007 & https://www.oie.int/wahis_2/public/wahid.php/Reviewreport/Review?reportid=5720 \\
\hline \multirow[t]{3}{*}{ Armenia } & 29/08/2007 & https://www.oie.int/wahis_2/public/wahid.php/Reviewreport/Review?reportid=6051 \\
\hline & $13 / 03 / 2010$ & https://www.oie.int/wahis_2/public/wahid.php/Reviewreport/Review?reportid=9032 \\
\hline & 28/09/2011 & https://www.oie.int/wahis_2/public/wahid.php/Reviewreport/Review?reportid=11075 \\
\hline Russia, South Ossetia Republic & 07/07/2008 & https://www.oie.int/wahis_2/public/wahid.php/Reviewreport/Review?reportid=7164 \\
\hline Azerbaijan & 29/01/2008 & https://www.oie.int/wahis_2/public/wahid.php/Reviewreport/Review?reportid=6730 \\
\hline Russia, Chechnya & 04/12/2007 & https://www.oie.int/wahis_2/public/wahid.php/Reviewreport/Review?reportid=6546 \\
\hline Russia, Irkutsk & $27 / 03 / 2017$ & https://www.oie.int/wahis_2/public/wahid.php/Reviewreport/Review?reportid=23385 \\
\hline Russia, Omsk & $14 / 07 / 2017$ & https://www.oie.int/wahis_2/public/wahid.php/Reviewreport/Review?reportid=24296 \\
\hline Russia, Krasnoyarsk & 06/10/2017 & https://www.oie.int/wahis_2/public/wahid.php/Reviewreport/Review?reportid=24965 \\
\hline Russia, Chelyabinsk & $01 / 12 / 2017$ & $\begin{array}{l}\text { https://www.oie.int/wahis_2/public/wahid.php/Reviewreport/Review?page_refer=MapFu } \\
\text { IIEventReport\&reportid=25174 }\end{array}$ \\
\hline Russia, Tyumen, Yamano-Nenets & $01 / 12 / 2017$ & https://www.oie.int/wahis_2/public/wahid.php/Reviewreport/Review?reportid=25218 \\
\hline Russia, Primorskiy, Amur, Yevreyskaya & $\begin{array}{c}\text { 05/08/2019; } \\
\text { 08/08/2019; } \\
\text { 12/09/2019 }\end{array}$ & $\begin{array}{l}\text { https://www.oie.int/wahis_2/public/wahid.php/Reviewreport/Review?page_refer=MapFu } \\
\text { IIEventReport\&reportid=31280 } \\
\text { https://www.oie.int/wahis_2/public/wahid.php/Reviewreport/Review? reportid=31337 } \\
\text { https://www.oie.int/wahis_2/public/wahid.php/Reviewreport/Review?reportid=31725 }\end{array}$ \\
\hline Khabarovskiy & $19 / 12 / 20$ & https://www.oie.int/wahis_2/public/wahid.php/Reviewreport/Review?reportid=32642 \\
\hline Ukraine & $31 / 07 / 2012$ & https://www.oie.int/wahis_2/public/wahid.php/Reviewreport/Review?reportid=12168 \\
\hline Belarus, Grodno & $21 / 06 / 2013$ & https://www.oie.int/wahis_2/public/wahid.php/Reviewreport/Review?reportid=13663 \\
\hline Belarus, Vitebsk & 07/07/2013 & https://www.oie.int/wahis_2/public/wahid.php/Reviewreport/Review?reportid=13736 \\
\hline Lithuania & $24 / 01 / 2014$ & https://www.oie.int/wahis_2/public/wahid.php/Reviewreport/Review?reportid=14690 \\
\hline Poland, Podlaskie & $17 / 02 / 2014$ & https://www.oie.int/wahis_2/public/wahid.php/Reviewreport/Review?reportid=14793 \\
\hline Poland, Lubuskie & $15 / 11 / 2019$ & https://www.oie.int/wahis_2/public/wahid.php/Reviewreport/Review?reportid=32385 \\
\hline Latvia & $26 / 06 / 2014$ & https://www.oie.int/wahis_2/public/wahid.php/Reviewreport/Review?reportid=15485 \\
\hline Estonia & 08/09/2014 & https://www.oie.int/wahis_2/public/wahid.php/Reviewreport/Review?reportid=16019 \\
\hline Moldova & 04/10/2016 & https://www.oie.int/wahis_2/public/wahid.php/Reviewreport/Review?reportid=21095 \\
\hline Czech Republic & $27 / 06 / 2017$ & https://www.oie.int/wahis_2/public/wahid.php/Reviewreport/Review?reportid=24159 \\
\hline Romania & $31 / 07 / 2017$ & https://www.oie.int/wahis_2/public/wahid.php/Reviewreport/Review?reportid=24456 \\
\hline Hungary, Heves & $\begin{array}{l}23 / 04 / 2018 \\
29 / 08 / 2019\end{array}$ & $\begin{array}{l}\text { https://www.oie.int/wahis_2/public/wahid.php/Reviewreport/Review?reportid=26484 } \\
\text { https://www.oie.int/wahis_2/public/wahid.php/Reviewreport/Review?reportid=31594 }\end{array}$ \\
\hline Hungary, Szabolcs Szatmar Bereg & 18/05/2018 & https://www.oie.int/wahis_2/public/wahid.php/Reviewreport/Review?reportid=26670 \\
\hline Hungary, Borsod Abauj Zemplen & 05/10/2018 & https://www.oie.int/wahis_2/public/wahid.php/Reviewreport/Review?reportid=28174 \\
\hline Bulgaria, Tutrakantsi & $31 / 08 / 2018$ & https://www.oie.int/wahis_2/public/wahid.php/Reviewreport/Review?reportid=27760 \\
\hline Bulgaria, Silistra & 23/10/2018 & https://www.oie.int/wahis_2/public/wahid.php/Reviewreport/Review?reportid=28379 \\
\hline Belgium & $14 / 09 / 2018$ & https://www.oie.int/wahis_2/public/wahid.php/Reviewreport/Review?reportid=27948 \\
\hline Slovakia & $25 / 07 / 2019$ & https://www.oie.int/wahis_2/public/wahid.php/Reviewreport/Review?reportid=31199 \\
\hline Serbia, Belgrade & $11 / 04 / 2019$ & https://www.oie.int/wahis_2/public/wahid.php/Reviewreport/Review?reportid=31342 \\
\hline Serbia, Pirotski, Borski & $\begin{array}{l}\text { 17/01/2020; } \\
\text { 03/02/2020 }\end{array}$ & $\begin{array}{l}\text { https://www.oie.int/wahis_2/public/wahid.php/Reviewreport/Review?reportid=32972 } \\
\text { https://www.oie.int/wahis_2/public/wahid.php/Reviewreport/Review?reportid=33115 }\end{array}$ \\
\hline Greece & 06/02/2020 & $\begin{array}{l}\text { https://www.oie.int/wahis_2/public/wahid.php/Reviewreport/Review?page_refer=MapFu } \\
\text { IIEventReport\&reportid=33221 }\end{array}$ \\
\hline
\end{tabular}

Additionally, although the presence of the classic sylvatic cycle has not been confirmed or, in most cases, adequately investigated, it is likely that it exists or historically existed in Angola, Burundi, Democratic Republic of Congo (DRC), Republic of Congo (Congo) and Rwanda
(Mulumba-Mfumu et al. 2019; Penrith et al. 2019). Ethiopia, where pig-keeping was a new activity, experienced its first outbreak in 2011, but genetic analysis of the outbreak viruses revealed subgenotypic variation that 
Table 4 Links to Immediate notifications to the World Organisation for Animal Health (OIE), 2007-2020: Asia and Oceania

\begin{tabular}{|c|c|c|}
\hline Country & Report date & URL \\
\hline China, Zheijiang & 23/08/2018 & $\begin{array}{l}\text { https://www.oie.int/wahis_2/public/wahid.php/Reviewreport/Review?repor } \\
\text { tid=27636 }\end{array}$ \\
\hline China, Jilin & $21 / 11 / 2018$ & $\begin{array}{l}\text { https://www.oie.int/wahis_2/public/wahid.php/Reviewreport/Review?repor } \\
\text { tid=28033 }\end{array}$ \\
\hline Hong Kong & $\begin{array}{l}\text { 12/05/2019; } \\
05 / 06 / 2019 \\
04 / 09 / 19\end{array}$ & $\begin{array}{l}\text { https://www.oie.int/wahis_2/public/wahid.php/Reviewreport/Review?repor } \\
\text { tid=30449 } \\
\text { https://www.oie.int/wahis_2/public/wahid.php/Reviewreport/Review?repor } \\
\text { tid=30685 } \\
\text { https://www.oie.int/wahis_2/public/wahid.php/Reviewreport/Review?repor } \\
\text { tid=31644 }\end{array}$ \\
\hline Mongolia & 15/01/2019 & $\begin{array}{l}\text { https://www.oie.int/wahis_2/public/wahid.php/Reviewreport/Review?repor } \\
\text { tid=29213 }\end{array}$ \\
\hline Vietnam & 20/02/2019 & $\begin{array}{l}\text { https://www.oie.int/wahis_2/public/wahid.php/Reviewreport/Review?repor } \\
\text { tid=29617 }\end{array}$ \\
\hline Cambodia & 03/04/2019 & $\begin{array}{l}\text { https://www.oie.int/wahis_2/public/wahid.php/Reviewreport/Review?repor } \\
\text { tid=30032 }\end{array}$ \\
\hline Korea, North & $30 / 05 / 2019$ & $\begin{array}{l}\text { https://www.oie.int/wahis_2/public/wahid.php/Reviewreport/Review?page_refer } \\
\quad=\text { MapFullEventReport\&reportid=30664 }\end{array}$ \\
\hline Laos, Sarvane & 20/06/2019 & $\begin{array}{l}\text { https://www.oie.int/wahis_2/public/wahid.php/Reviewreport/Review?repor } \\
\text { tid=30807 }\end{array}$ \\
\hline Laos, Vientane & $11 / 07 / 2019$ & $\begin{array}{l}\text { https://www.oie.int/wahis_2/public/wahid.php/Reviewreport/Review?repor } \\
\text { tid=31056 }\end{array}$ \\
\hline Laos. Huaphanh & 08/10/2019 & $\begin{array}{l}\text { https://www.oie.int/wahis_2/public/wahid.php/Reviewreport/Review?repor } \\
\text { tid=32036 }\end{array}$ \\
\hline Philippines, Luzon Island & 09/09/2019 & $\begin{array}{l}\text { https://www.oie.int/wahis_2/public/wahid.php/Reviewreport/Review?repor } \\
\text { tid=31677 }\end{array}$ \\
\hline Philippines, Mindanao Island & 03/02/2019 & $\begin{array}{l}\text { https://www.oie.int/wahis_2/public/wahid.php/Reviewreport/Review?repor } \\
\text { tid=33135 }\end{array}$ \\
\hline Myanmar & 14/08/2019; 17/02/2020; 04/03/2020 & $\begin{array}{l}\text { https://www.oie.int/wahis_2/public/wahid.php/Reviewreport/Review?repor } \\
\text { tid=31365 } \\
\text { https://www.oie.int/wahis_2/public/wahid.php/Reviewreport/Review?page_refer } \\
\text { =MapFullEventReport\&reportid=33311 } \\
\text { https://www.oie.int/wahis_2/public/wahid.php/Reviewreport/Review?page_refer } \\
\quad=\text { MapFullEventReport\&reportid=33501 }\end{array}$ \\
\hline Timor-Leste & 27/09/2019 & $\begin{array}{l}\text { https://www.oie.int/wahis_2/public/wahid.php/Reviewreport/Review?repor } \\
\text { tid=31960 }\end{array}$ \\
\hline Indonesia & $17 / 12 / 2019 ; 13 / 03 / 2020$ & $\begin{array}{l}\text { https://www.oie.int/wahis_2/public/wahid.php/Reviewreport/Review?repor } \\
\text { tid=32482 } \\
\text { https://www.oie.int/wahis_2/public/wahid.php/Reviewreport/Review?repor } \\
\text { tid=33618 }\end{array}$ \\
\hline Korea, South & $17 / 09 / 2019$ & $\begin{array}{l}\text { https://www.oie.int/wahis_2/public/wahid.php/Reviewreport/Review?repor } \\
\text { tid=31778 }\end{array}$ \\
\hline Papua New Guinea & $30 / 03 / 2020$ & $\begin{array}{l}\text { https://www.oie.int/wahis_2/public/wahid.php/Reviewreport/Review?page_refer } \\
\quad=\text { MapFullEventReport\&reportid=33803 }\end{array}$ \\
\hline India & $19 / 05 / 20$ & \\
\hline
\end{tabular}

suggested a longer presence and therefore possible warthog involvement (Achenbach et al. 2017).

As the virus remains endemic in its sylvatic hosts, the infection cannot be eradicated from the sub-region, and outbreaks due to spill-over from the sylvatic cycle occur when proper separation between wild and domestic pigs is not in place (Penrith et al. 2013). However, in countries where relatively large numbers of pigs are kept in traditional free-ranging systems or smallholder and backyard farms with low biosecurity, ASF virus circulates independently of the sylvatic hosts, which in many cases are only to be found in designated conservation areas where there are no domestic pigs (Haresnape et al. 1988; Penrith et al. 2019). Warthogs may be extinct in Republic of Congo (de Jong et al. 2016). The only recent report that suggested a source of outbreaks in eastern Congo close to the border of DRC attributed the infection to importation of 
pigs from DRC soon after that country had reported outbreaks of ASF (Mulumba-Mfumu et al. 2019).

\section{Trends and challenges for control}

While ASF is endemic in domestic pigs in a number of countries in which the sylvatic cycle is known or believed to exist, Botswana, Namibia, South Africa and Zimbabwe until recently had only experienced sporadic outbreaks involving single farms or villages that could with reasonable confidence be attributed to spill-over from the sylvatic cycle (Mulumba-Mfumu et al. 2019). Recently, with the exception of Botswana, which has very few pigs, these countries have experienced outbreaks in domestic pigs that were either unrelated to the sylvatic cycle or may have been initiated by spill-over from the sylvatic cycle but subsequently spread markedly amongst domestic pigs.

In Namibia outbreaks of ASF occurred in 2009 in a backyard farm, a prison and villages in the Omusati and Oshana districts close to the border with Angola (Simulundu et al. 2017) (Table 2). Although according to the reports warthog involvement was suspected, the subsequent spread was more likely due to infectious pigs and pork. In South Africa, outbreaks in the ASF controlled area in domestic pigs still appear to be linked to the sylvatic cycle (Janse van Rensburg et al. 2020a). However, although occasional sylvatic cyclerelated incidents occurred in the ASF free area close to the border of the ASF controlled area from its proclamation in 1935 until 2011, 2012 saw the first outbreaks in the free area that, although suspected to have originated in the controlled area, spread significantly among domestic pigs (Geertsma et al. 2012; Magadla et al. 2016). Between 2016 and 2019 outbreaks have occurred in several parts of the free area in three provinces (Janse van Rensburg et al. 2020b). These may have been initiated in the sylvatic cycle due to the introduction of infected warthogs into new areas (Swanepoel M, Leslie AJ, Hoffman LC. Farmers' perceptions of the extra-limital common warthog in the Northern Cape and Free State Provinces, South Africa. Wildlife Society Bulletin 2011) but in most of the outbreaks there was notable spread attributed to movement of infected pigs and feeding infected swill (Janse van Rensburg et al. 2020b). Finally, after an absence of outbreaks of ASF since 1992, Zimbabwe experienced an outbreak of ASF in 2015 in Mashonaland Central province in villages close to the border with the Tete Province of Mozambique. The pigs were free-ranging and the outbreak was attributed to movement of infected pigs and pork and careless carcass disposal (van Heerden et al. 2017). In January 2019 similar outbreaks were reported in freeranging pigs in Manicaland Province, on the border with Manica Province in Mozambique, and in August/ September 2019 outbreaks were again experienced in Mashonaland Central (Table 2).

It is likely that the shift from isolated outbreaks related to the sylvatic cycle to notable involvement of domestic pigs in previously unaffected areas can be attributed to a marked increase in pig production, largely by smallholder pig producers. Figures available in South Africa indicated that the number of households keeping pigs almost doubled between 2011 and 2016, about 90 per cent of whom kept 10 or fewer pigs (Janse van Rensburg et al. 2020b). It was previously noted that an increase in the pig population in subSaharan Africa was accompanied by an increase in the number of outbreaks of ASF (Penrith et al. 2013).

Controlling ASF in a domestic pig cycle presents different challenges from preventing spill-over from the sylvatic cycle, which is usually simply a matter of ensuring adequate separation between pigs and warthogs. In Africa, the domestic cycle is largely driven by poverty amongst subsistence level pig farmers. To profit from their pigs, these farmers resort to practices that are risky for ASF, such as allowing pigs to scavenge or feeding them waste food, failing to implement even basic biosecurity measures, buying pigs as cheaply as possible from uncertain sources, not reporting disease and selling off pigs as soon as one pig shows signs of ASF (Chenais et al. 2017; Chenais et al. 2019; Dione et al. 2017; Dione et al. 2016; Lichoti et al. 2016). Providing incentives for change is the most important challenge for ASF control in this region.

\section{Historically free (no sylvatic cycle) areas in West and Central Africa and Indian Ocean}

Although warthogs are widely distributed in savannah areas in West Africa and northern Central Africa, the classic sylvatic cycle has not been demonstrated to occur there, probably due to the absence of Ornithodoros moubata complex ticks from the West African region south of $13^{\circ} \mathrm{N}$ (Etter et al. 2011; Trape et al. 2013). Absence of the ticks from the main pig-producing areas in Cameroon was also reported (Ekue and Wilkinson 1990). Limited serological examination of warthogs in Senegal and Nigeria failed to detect antibodies (Etter et al. 2011; Sarr J, Diop M. Situation épizootiologique de la peste porcine africaine au Sénégal. Institut Sénégalais de Recherche Agricole, Laboratoire de l'Élevage et de Recherches Vétérinaires, Dakar, Senegal (unpublished report) 1990; Taylor et al. 1977). Detection of ASF virus in a baby warthog and a Red River hog (Potamochoerus porcus) in Nigeria (Luther et al. 2007a, b) was likely due to spill-over from the outbreaks that were widespread in pigs at the time. In 
Senegal, specimens of Ornithodoros sonrai collected from rodent burrows in earth-floored pig pens tested positive for ASF virus (Vial et al. 2007) but are considered unlikely to play an important role in the persistence of ASF virus in the country as they are not present in the endemic area, which lies south of $13^{\circ} \mathrm{N}$ (Etter et al. 2011).

The classic sylvatic cycle is also absent from the Indian Ocean Islands, where warthogs are not present. Although ASF became endemic in Madagascar after the first outbreaks were reported in 1998, there is no indication that the presence of a population of southern bushpigs (Potamochoerus larvatus) in the north of the island or of Ornithodoros moubata complex ticks plays any role in the epidemiology of the disease (Jori et al. 2013). In Mauritius, there are no wild African suids or Ornithodoros moubata complex ticks (Lubisi et al. 2009; Jori et al. 2013). The only free-ranging pigs are the descendants of domestic pigs from Europe introduced by sailors centuries ago (Oliver W, Brisbin I. Introduced and feral pigs: Problems, policies and priorities. The Eurasian Wild Pig. In: Oliver, WLB, editor. Pigs, Peccaries and Hippos Status Survey and Action Plan. Gland: IUCN/SSC 1993) that are either farmed or kept on large estates for hunting purposes. The single incursion of ASF was rapidly eradicated (Lubisi et al. 2009).

Endemic establishment of the disease in regions without the sylvatic cycle can therefore be ascribed to continuous circulation of the virus in pig populations with a high level of contact, for example in free-ranging populations that commonly occur in West Africa (Brown et al. 2018).

\section{Trends and challenges for control}

In West Africa, since 2017 two new countries reported outbreaks and Côte d'Ivoire has again experienced outbreaks after eradicating ASF by 1997. Two countries in Central Africa have become endemically infected since 2010.

An outbreak occurred in Mali in 2016, close to the border with endemically infected Burkina Faso (Table 2). After the introduction of ASF in 1996 Côte d'Ivoire succeeded in eradicating the disease with the last few outbreaks reported in October 1996 (El Hicheri et al. 1998). An outbreak occurred in the port city of San Pedro in 2014 (Table 2), probably due to scavenging pigs having access to ships' galley waste (Couacy-Hymann et al. 2019). The outbreak was eradicated after limited spread, but in 2017 and 2019 further outbreaks occurred. The first was in the north of the country in Ferkessedougou with spread to the neighbouring district of Korhogo. It was reported that prior to the outbreak there had been pig mortalities close to the border with Burkina Faso
(Table 2). The 2019 outbreaks occurred in two districts in the south eastern part of the country not sharing a border with another country. The outbreak was ascribed to the 'introduction of new live animals', the origin of which was not given (Table 2). Sierra Leone reported ASF to OIE for the first time in 2019 (Table 2), but the disease may have been present in the country for at least 3 years (Wadoum et al. 2020).

After an outbreak in the previously unaffected Extreme North district in Cameroon in 2010, ASF spread to Chad and appears to have become established (Table 2). The introduction was traced to a city close to the border with the affected area in Cameroon and was believed to be due to infected pigs or pork brought from that country (Bidjeh et al. 2015), followed by spread to other parts of Chad. Central African Republic (CAR) also reported an outbreak in 2010 but this may not have been linked to the Cameroon and Chad outbreaks, as it occurred far from the borders of those countries and the OIE Animal Health Information Department noted that a suspicion of ASF had already been reported in 2009. Subsequently reporting has been biennial as for endemic countries (Table 2). The existence of the sylvatic cycle has not been investigated in either Chad or CAR. In CAR an association between Ornithodoros moubata complex ticks and warthogs apparently exists, as one nymph collected from a warthog has been reported (Uilenberg et al. 2013). Neither country had previously officially reported ASF.

With endemic infection present in several countries in West Africa, Central Africa and also in Madagascar, these regions pose a risk of ASF in spite of the absence of the sylvatic cycle. Although African exports of pork outside the continent are insignificant, intra-regional trade occurs at both formal and informal levels (Bidjeh et al. 2015; FAO. Secteur Porcin Burkina Faso. Revues nationales de lélevage de la division de la production et de la santé animales de la FAO. No. 1. Rome: Food and Agriculture Organization of the United Nations 2012; Kouakou et al. 2017; Dutuertre G. Les facteurs de competitivité de la filière porcine dans la Bassin du Logone. 2002). Movement of people between countries due to economic imperatives or civil wars is also common and can result in movement of infected products. Traditional transhumance due to trade or climatic factors overwhelmingly involves ruminants and camels, but as borders frequently divide closely related communities, transfer of live pigs for ceremonies commonly occurs (Penrith et al. 2013; Kouakou et al. 2017). The recent introductions into Côte d'Ivoire and Mali are believed to have originated in the region, including the introduction to the former via the port of San Pedro (Couacy-Hymann et al. 2019). The virus that caused the 2007 incursion into Mauritius had 
been circulating in Mozambique and Madagascar since at least 1998 (Lubisi et al. 2009).

The Mauritius and San Pedro incursions were attributed to the consumption by pigs of inadequately disposed waste food from ships containing infected pork (Lubisi et al. 2009; Couacy-Hymann et al. 2019), and this remains the greatest risk for long distance introductions of ASF.

Challenges are similar to those now being experienced in endemic areas when the sylvatic cycle spills over with continuation in domestic pigs. Risks in the way pigs are farmed and traded include free-ranging production systems that permit scavenging on potentially infected material, feeding of waste food to pigs, generally low levels of biosecurity on premises where pigs are kept and informal trading systems (Bidjeh et al. 2015; Brown et al. 2018; Wadoum et al. 2020; Dione et al. 2017; FAO. Secteur Porcin Burkina Faso. Revues nationales de l'élevage de la division de la production et de la santé animales de la FAO. No. 1. Rome: Food and Agriculture Organization of the United Nations 2012; Andriamanivo et al. 2019; Asambe et al. 2017; Costard et al. 2009; Fasina et al. 2012; Randrianantoandro et al. 2015). The challenge is how to mitigate the risks to reduce or eliminate losses due to ASF and make smallholder pig production more profitable and sustainable.

\section{Europe and Transcaucasus}

The current situation in Europe is described country by country, in chronological order of their reporting ASF, and the trends and challenges will be presented at the end of the section. The same format has been followed for Asia.

\section{Transcaucasus}

The Transcaucasus is a region at the junction of Europe and Asia, and comprises of Georgia, Armenia and Azerbaijan, as well as a part of southern Russia.

Domestic pigs in Georgia, Armenia and Azerbaijan are currently free from ASF. Since 2007, when multiple outbreaks of ASF were reported in domestic pigs in Georgia (Table 3), and 2010-2011, when ASF re-emerged (Vepkhvadze et al. 2017), no further outbreaks have been reported. A serological survey carried out in domestic pigs in 2014 in which 1231 pigs proved negative for antibodies to ASF virus suggested that the virus is not being maintained in domestic pig populations in Georgia, but the ASF situation in wild boars is unknown (Vepkhvadze et al. 2017). According to a report to EFSA, ASF spread continues in South Ossetia (Depner et al. 2017), which lies within the Republic of Georgia but since 2008 has existed as an independent republic under Russian protection, similar to Abkhazia, which was affected by ASF at the same time as Georgia (Gogin et al. 2013). South
Ossetia experienced its first ASF outbreak in June 2008 (Table 3).

The first ASF outbreak in Armenia notified to OIE was on a commercial farm in Tavush Marz in the north of the country in August 2007, followed by outbreaks in backyard and village farms in both northern districts (Tavush and Lori Marz) (Table 3) as well as Yerevan and Ararat, with an additional case in February 2008 (Rahimi et al. 2010). No outbreaks were officially reported in 2008 and 2009, but a second wave of infection is reported to have occurred on farms in Tavush Marz in 2009, infecting greater numbers of pigs than in 2007 (Sargsyan et al. 2018). In March 2010, outbreaks occurred in a small commercial farm in Tavush Marz, in feral pigs in a forest in Lori Marz, and two wild boars in Vayots Dzor, and in 2011 outbreaks were reported in village pigs in Siunik, Kotayk, Aragatsotn, Armavir and Tavush (Table 3). Further outbreaks occurred on farms in Tavush Marz in late autumn to early winter of 2011 (Sargsyan et al. 2018). Since 2011 no further outbreaks in domestic pigs have been reported, but the wild boar status is unknown. The outbreaks in village pigs in the southernmost province of Siunik not long after ASF-positive wild boars were identified in the adjacent province of Vayots Dzor just to the north of Syunik, as well as the positive wild boars identified in north-western Iran in 2008 and 2009 (Rahimi et al. 2010) suggest circulation of the virus in wild boar populations occurred, at least during that period. Since ASF was confirmed by the Armenian Veterinary Services in the disputed territory of Nagorno Karabakh in October $2013,{ }^{2}$ almost 2 years after the last reported outbreak in pigs in Armenia, it is possible that wild boars may have been source of the infection.

Azerbaijan reported a single ASF outbreak in January 2008, in one village inhabited by Christian people with about 4600 pigs (Table 3). The source of infection was most likely infected pork imported from Georgia, in the absence of evidence of infected wild boars (Beltran Alcrudo D, Lubroth J, Depner K, De la Rocque S. African swine fever in the Caucasus. EMPRES Watch, April 2008).

Challenges that remain in the Transcaucasus are the existence of disputed territories and the unknown situation in wild boars.

\section{Europe \\ Sardinia (Italy)}

Unlike the other affected European countries, Sardinia has experienced ASF since 1978 (Laddomada et al. 2019; Mur et al. 2016; Cappai et al. 2018; Iglesias et al. 2017). There is no evidence of involvement of Ornithodoros

\footnotetext{
${ }^{2}$ https://armenpress.am/eng/amp/519844.
} 
ticks in ASF in Sardinia (Mur et al. 2017). The only species of the genus known to occur on the island is associated with sea birds and is found in habitats where pigs are unlikely (Fois et al. 2016). Both domestic pigs and wild boars were infected, and persistence of the virus has depended largely upon circulation in free-ranging pig populations (Laddomada et al. 2019; Mannelli et al. 1997; Mur et al. 2018). It has generally been accepted that wild boars play a secondary role to infected domestic pigs (Mur et al. 2016; Laddomada et al. 1994), but under some circumstances they may play a more important role (Mur et al. 2016; Mur et al. 2018). There is no evidence that Sardinia has ever been a source of infection for other countries.

\section{Russia}

The first ASF outbreak on Russian Federal territory was recorded in December 2007 in dead wild boars along the Argoun and Argoun-Shatoy rivers in Chechnya Republic on the border with Georgia (Table 3). Its subsequent spread in Russian territories between 2007 and 2012 has been well documented (Gogin et al. 2013). It can now be considered endemic in most of European Russia with new outbreaks reported in domestic pigs and/or wild boars in 26 administrative regions between 2018 and 2020, including a number of large commercial pig farms (Disease information-Immediate notifications 2005-2020).

Since 2017 there has been concerning expansion of ASF eastwards (Disease information-Immediate notifications 2005-2020). Outbreaks have occurred in the eastern federal districts of Urals (Chelyabinsk, Omsk, Tyumen, Yamalo-Nenetsky), Siberia (Irkutsk and Krasnoyarsk) and most recently (2019-2020) in the Far East (Amurskaya, Khabarovsk, Primorskiy and Yevreyskaya Avtonomnaya Oblast) (Table 3). These last outbreaks have been concentrated along the border with China. The virus that was isolated from the outbreak in Irkutsk, Siberia in 2017 proved to be identical to the original virus introduced into Russia in 2007 and is now comparatively rare among recent Russian isolates (Kolbasov et al. 2018).

The first outbreak in the Far East occurred on a small farm with 70 pigs in Primorskiy Kray in July 2019, followed a few days later on 5 August 2019 by an outbreak in village pigs in Amurskaya Oblast (Table 3). At about the same time, two outbreaks involving 7 wild boars were identified in forest in the same general area as the first outbreak in Primorskiy Kray. Outbreaks have occurred among domestic pigs and wild boars in Yevreyskaya Avtonomnaya Oblast and in wild boars in Khabarovskaya Krai in 2019 (Table 3). Outbreaks in wild boars in Amurskaya Oblast were registered in 2019 and 2020, and also in wild boars in 2020 (Table 3).
All the outbreaks in the Urals region and Siberia occurred in domestic pigs, with no evidence for a link to wild boars. On the other hand, cases in wild boars have occurred in the Far East. However, considering the distance between the Far East and the nearest known infections in wild boars in European Russia, it is extremely unlikely that Russian wild boars could be implicated in an ASF introduction to the Far East. Infection in wild boars has been reported only in three localities in China, none of them particularly close to the Russian Far East. However, there were outbreaks of ASF in the adjacent Chinese province of Heilongjiang in domestic pigs in early September 2018, and since the first outbreaks of ASF in August 2018 in Liaoning Province in China (Zhou et al. 2018) the situation in China has remained dynamic, with ASF having spread throughout the country within months of the initial outbreaks.

\section{Ukraine}

Apart from an outbreak in Odessa in 1977 when it was still part of the USSR (Korennoy et al. 2017), Ukraine experienced its first outbreak of ASF in domestic pigs in July 2012, in the Zaporozh'Ye district in village pigs (Table 3). No further outbreaks were reported in 2012 or 2013, but in January 2014 ASF was detected in a wild boar, a backyard pig farm and some village pigs in Lugansk, which shares a border with Russia (Disease information-Immediate notifications 2005-2020). From that time to the present, Ukraine has reported numerous outbreaks in both wild boars and domestic pigs (Disease information-Immediate notifications 2005-2020). In 2016 outbreaks occurred in Odessa and Chernovtsy districts that share borders with Moldova and the latter district also with Romania. By the end of 2017 ASF had been reported in all of the administrative districts of Ukraine, mostly in both wild boars and backyard pigs as well as in mainly small farms. Large numbers of immediate notifications submitted between 2018 and April 2020 indicate that active circulation of the virus continues in Ukraine (Disease information-Immediate notifications 2005-2020).

\section{Belarus}

Belarus has only reported two ASF outbreaks, both in 2013. The first occurred in June 2016 in village pigs in the Grodno district in the west that shares a border with Lithuania (Table 3). The second, at the beginning of July, was on a commercial cooperative farm with 20,611 pigs close to the eastern side of the Vitebsk district that shares borders with Latvia to the west and Russia to the east. The Grodno outbreak was attributed to contaminated feed and the origin of the Vitebsk outbreak was not determined (Table 3). Both outbreaks were rapidly resolved. 


\section{Lithuania}

The first outbreak was reported in wild boars found close to the border with Belarus in January 2014 and ASF continues to the present in wild boars (Table 3). The last outbreak in domestic pigs was reported to OIE in 2018. Up to the end of 2017 two out of 52 outbreaks were recorded in commercial pig farms, the majority of cases having occurred in backyard holdings (Pautenius et al. 2018). Outbreaks in both wild boars and domestic pigs increased markedly in 2017 and 2018 (Mačiulskis et al. 2020; Pautenius et al. 2018). A study on buried wild boar carcasses in Lithuania failed to demonstrate the presence of infectious virus in samples from the carcasses or the adjacent soil (Zani et al. 2020), suggesting that environmental persistence may not present a long-term threat of ASF.

\section{Poland}

In Poland, the first identification of the ASF virus was in February 2014 in a sample from a dead wild boar found $900 \mathrm{~m}$ from the border with Belarus in the Hajnowski region of the Podlaskie district (Pejsak et al. 2014) (Table 3). By 31 August several more cases in wild boars and two outbreaks in backyard pig farms, all close to the border with Belarus, had been diagnosed (Pejsak et al. 2014). The first 18 months of the virus presence in Poland were characterised by repeated introductions of the virus via wild boars close to the Belarus border, followed by the disease spreading slowly in areas heavily populated with wild boars, which had a dominant role in maintaining the virus (Smietanka et al. 2016). Reports to OIE reflected spread of the disease over the next years to neighbouring districts on the eastern border of Poland. The first outbreaks in wild boars and domestic pigs in Lubelskie to the south and Mazowieckie to the west were reported in 2016, followed by Warminsko-Mazurski to the north in wild boars in 2017 and domestic pigs in 2018. A few outbreaks were reported in domestic pigs from Podkarpackie, to the south of Lubelskie, in 2018 (Disease information-Immediate notifications 2005-2020). The genotype II viruses isolated from samples taken from two wild boars in Lithuania and two in Poland indicated a variant that was identical to isolates from Belarus and Ukraine (Gallardo et al. 2014), but this was not able to confirm the origin of the viruses, as the same variant was reported to have been circulating rather widely in southern and central Russia since 2012 (Goller et al. 2015).

Until 2018, ASF remained confined to the infected districts in the east of Poland. The need to prevent transfer of the infection in wild boars to new areas through human activities was foreseen in an epidemiological study of ASF in wild boars in Poland over a four-year period (Pejsak et al. 2018). However, in 2019 infected wild boars were found in Lubuskie district in the west of Poland close to the border with Germany, more than $500 \mathrm{~km}$ from the infected eastern districts (Table 3) and subsequently in the neighbouring district of Wielpolskie (Disease information-Immediate notifications 20052020). Most recently two outbreaks of ASF on commercial pigs farms in western Poland have been reported by ProMED-mail. The first occurred in Lubuskie district, affecting more than 23,700 pigs $^{3}$ on a commercial farm $66 \mathrm{~km}$ from the German border; it was reported that wild boar carcasses had been seen near the pig houses. On 4 April 2020 ProMED-mail posted the news that an outbreak of ASF had been confirmed on a commercial farm in Wielkopolskie ${ }^{4}$ near Poznan, less than $150 \mathrm{~km}$ from the border with Germany. It is evident that these outbreaks could not have been caused by natural migrations of wild boars, and that anthropogenic activities offer the only plausible explanation.

\section{Latvia}

Three dead wild boars found close to the border with Belarus in June 2014 tested positive for ASF (Table 3). Following this event, 32 cases occurred on pig farms and 217 in wild boars during the remainder of 2014 (Olsevskis et al. 2014). The outbreaks in domestic pigs were in backyard holdings, the majority (20) with fewer than 10 pigs and the largest with 196 pigs, and all were attributed to breaches of biosecurity. The last outbreak in a pig farm was reported in July 2019, with 10 reports of ASF in pig farms in 2018 (Disease information-Immediate notifications 2005-2020), but reports of infected wild boars continued into 2020. An evaluation of the current epidemiological situation in wild boars indicated a decrease in active circulation of the virus and suggested that managing the wild boar population to keep numbers as low as possible, continuing surveillance and removal of wild boar carcasses could result in elimination of the infection (Olsevskis et al. 2020). An experimental oral vaccine developed from a field strain of reduced virulence recovered from a wild boar in Latvia was reported to show promise (Barasona et al. 2019).

\section{Estonia}

A dead wild boar was discovered in Valga County $6 \mathrm{~km}$ from the border with Latvia in September 2014 (Table 3). The first pig farm was affected in July 2015. From 2015 to 2017 there were 26 outbreaks in pig farms, involving both backyard and large commercial farms, with lower

\footnotetext{
${ }^{3}$ Based on media report: https://www.pigprogress.net/Health/Artic les/2020/3/ASF-Poland-First-outbreak-on-farm-in-Western-Poland-559288E/.

4 Based on media report: https://www.theguardian.com/environmen t/2020/apr/08/african-swine-fever-outbreak-reported-in-western-poland.
} 
mortality observed on the commercial farms (Nurmoja et al. 2018). There were 17 outbreaks in domestic pigs in 2015, 6 in 2016 and 3 in 2017, while in wild boars there were 1095 outbreaks in wild boar in 2015, 1570 in 2016 and 867 in 2017. An 18th outbreak in pigs reported and investigated in 2015 could not be confirmed, as samples from dead pigs were not available and the remaining pigs on the farm were negative for virus and antibodies (Nurmoja et al. 2018). Eighty-eight per cent of the outbreaks in domestic pigs occurred in areas where there were also outbreaks in wild boars within a $15 \mathrm{~km}$ radius of the farm. The reduced risk of outbreaks in pig farms may have been due to a marked reduction in the number of backyard holdings over the three-year period. The number fell from 696 in 2014 to 25 in 2017 owing to the imposition of strict biosecurity requirements for all pig farms (Nurmoja et al. 2018).

All the outbreaks in domestic pigs were detected in summer. Summer high incidence was ascribed to more wild boar activity closer to farms. Blood-sucking arthropods could also be involved and requires investigation but one would expect more outbreaks if they were important, as well as more cases within herds (Nurmoja et al. 2018). A survey has been conducted to determine the species of Diptera associated with Estonian pig farms (Tummeleht et al. 2020). A preliminary investigation of trapped Diptera detected traces of ASF virus in two flies and two mosquitoes, but further investigations to determine whether these insects could maintain and transmit infectious ASF virus are required (Herm et al. 2020).

An ASF virus strain with a consistent deletion of 14,560 base pairs at the $5^{\prime}$ end and consequent reorganisation of the genome was identified from field samples in north-eastern Estonia and under experimental conditions showed reduced virulence in trials with domestic and miniature pigs (Zani et al. 2018). High virulence was observed for a virus that caused outbreaks in another part of the country at the same time, so a general decline in virulence in Estonia is unlikely. Both in Estonia and Latvia the virus appeared to be of low contagiousness and spread slowly (Nurmoja et al. 2018; Olsevskis et al. 2014), but the case fatality rate was high.

Analysis of surveillance data in wild boars in Estonia provided some cause for optimism that incidence in wild boars was declining, suggesting that control measures might be achieving some success and achieving eradication of the infection in the wild boar population (Schulz et al. 2019; Schulz et al. 2020).

\section{Moldova}

The first two outbreaks were reported in September 2016 in backyard farms not far from the Ukrainian border (Table 3) and were attributed to swill feeding, using meat brought from Ukraine on a public holiday some 6 weeks previous to the primary outbreak. ${ }^{5}$ Since that time the country has suffered repeated outbreaks in both domestic pigs and wild boars. Until 2018 the majority of outbreaks involved mostly backyard pig farms, but in 2019 outbreaks in wild boars considerably outnumbered those in pig farms, and this trend continues into 2020 (Disease information-Immediate notifications 2005-2020).

\section{Czech Republic}

The first outbreak occurred in wild boars in Zlin district in late June 2017 (Table 3). In the immediate notification it was suggested that two wild boars found dead had crossed the Czech border with Slovakia, which had never reported ASF in spite of the usual EU surveillance. The nearest known infected wild boar population was $400 \mathrm{~km}$ away in Poland. It was later concluded the source of the infection was likely raw bacon discarded by a laundry worker from Ukraine in the hospital behind which the wild boars were found. ${ }^{6}$ Some local spread had occurred among wild boars. Using the approaches of careful definition of infected area, a complete ban on hunting within that area, intensive surveillance for dead boars and subsequent testing, and finally depopulation of the remaining wild boars resulted in eradication of ASF, the first time that ASF has been eradicated in a free-living wild population (Marcon et al. 2020). Eradication was confirmed in a self-declaration of freedom from ASF accepted by the OIE in 2019 (Table 1).

\section{Romania}

The first report was in July 2017 in a backyard farm in the Satu-Mare district and the source of infection was not determined at the time of reporting (Table 3). Further outbreaks in backyard farms and wild boars were reported in 2017 and 2018 in the same district, which shares borders with Hungary and Ukraine (Disease information-Immediate notifications 2005-2020). In 2018 outbreaks in backyard farms and to a lesser extent wild boars occurred in a number of districts from the north east of the country to the Black Sea coast (Disease information-Immediate notifications 2005-2020). Until July 2018 outbreaks involved backyard farms and sometimes wild boars, but after numerous outbreaks in backyard farms and a few in wild boars in the Tulcea district, an outbreak occurred on a large breeding farm with more than 40,000 pigs. $^{7}$ Over time there was a shift from

\footnotetext{
${ }^{5}$ Information from a ProMED-mail posting available at https://promedmail .org/promed-post/?id=20160929.4525246.

6 https://ec.europa.eu/food/sites/food/files/animals/docs/reg-com ahw_20170918_african_swine_fever_wild_boars_cze.pdf.

7 Based on media report, http://promedmail.org/post/20180704.5887708.
} 
backyard farms to wild boars as the main victims of ASF. OIE immediate notifications reflect 1310 outbreaks in domestic pigs and 549 in wild boars, with 21 in domestic pigs and 34 in wild boars in 2019 and 79 in domestic pigs and 250 in wild boars so far registered in 2020 (Disease information-Immediate notifications 2005-2020).

\section{Hungary}

So far only wild boars have been affected by ASF in Hungary. The first of 893 cases was registered in Heves district in April 2018 (Table 3). The area is heavily industrialised, with employment of foreign workers, and the source was believed to be waste food. In May 2018 a dead boar in Szabolcs-Szatmar-Bereg district about $1 \mathrm{~km}$ from the border with Ukraine was positive for ASF, and considering the level of infection in wild boars in Ukraine it seemed likely that the outbreak was the result of the normal wild boar spring migration (Table 3 ). This outbreak involved 211 events in 2018 (Disease informationImmediate notifications 2005-2020). A third outbreak, of undetermined origin and involving 1938 cases, started in Borsod-Abauj-Zemplen district in September 2018 (Table 3). Outbreaks continued through 2019 to the present at localities widely spread over the eastern half of the country, including at one locality close to the border of Romania (Disease information-Immediate notifications 2005-2020). A series of 239 outbreaks in Heves in August 2019 were considered to represent a new epidemiological unit along the Tisza River, south of the M3 motorway (Disease information-Immediate notifications 2005-2020).

\section{Bulgaria}

The first outbreak occurred in the Varna district in a backyard pig farm in Tutrakantsi in August 2018 (Table 3). A study of this outbreak could not determine the source of infection but identified anthropogenic factors linked to the potential for unrestricted human access to the pigs in spite of their secure confinement as the highest probability for introduction of the virus (Zani et al. 2019).This was followed by the diagnosis of ASF in a dead wild boar found entangled in a fence on the border with Romania in the district of Silistra (Table 3). The following months saw reports of further outbreaks in wild boars and in domestic pigs in backyard holdings as well as a large industrial farm and a breeding farm; subsequently deaths of wild boars due to ASF were reported from the same area (Disease information-Immediate notifications 2005-2020). Further ASF cases were confirmed in wild boars at localities in the north-eastern area where the previous outbreaks had occurred but also at two localities in the south, near to the border with Greece (Disease information-Immediate notifications 2005-2020).

\section{Belgium}

The first case was reported in September 2018 in the Luxembourg province of Belgium in wild boars (Linden et al. 2018) (Table 3). The source of the infection was not determined, but the distance from the nearest infected wild boar population, namely Czech Republic $1000 \mathrm{~km}$ away, pointed to anthropogenic factors (Gilliaux et al. 2019). The virus isolated proved to be a variant of the genotype II virus originally introduced into Georgia from Africa in 2007 that was most similar to viruses that were identified in Ukraine, Belarus, Estonia, European Russia and China between 2012 and 2018 (Garigliany et al. 2019). Sequencing of the complete genome revealed that of the ASF viruses for which information on complete sequencing of the genome is available, the Belgian isolate most closely resembled a 2014 isolate from Estonia (Gilliaux et al. 2019). Experimental infection of young wild boars with the Belgian 2018/1 isolate confirmed its high virulence in wild boars (Pikalo et al. 2020). In spite of the outbreaks in wild boars, Belgium reaffirmed their self-declaration of freedom in domestic pigs and captive feral pigs in May 2019. ${ }^{8}$ Outbreaks in free-living wild boars continued into 2019, with relatively large numbers of cases reported up to March, with marked tapering off from April to July and the last fresh case reported on 11 August 2019. The last reports from 21 October 2019 to 14 April 2020 concerned the bones of wild boars estimated to be from 3 to 6 months old, suggesting that the last cases may have occurred in September 2019 (Disease information-Immediate notifications 2005-2020).

\section{Slovakia}

Outbreaks of ASF were reported in backyard farms in July and August 2019 in the Kosice district close to the border with Hungary (Table 3), with reported cases in wild boars in the same area from August 2019 to April 2020 (Disease information-Immediate notifications 2005-2020).

\section{Serbia}

The first outbreak in Serbia was reported in domestic pigs in a village in the Belgrade district in August 2019. ${ }^{9}$ Altogether 18 outbreaks occurred between July and November 2019 (Table 3), mainly in the same area in Belgrade district but also in the adjacent Podunavski district and the Srednji Banatski district on the border with Romania.

The first outbreaks in Serbia reported in wild boars occurred in January 2020 in the Pirot and Bor districts,

\footnotetext{
${ }^{8}$ https://www.oie.int/fileadmin/Home/eng/Animal_Health_in_the_World/ docs/pdf/Self-declarations/2019_04_Belgium_ASF_ANG.pdf.

${ }^{9}$ Based on a media report in Bosnian, http://promedmail.org/post/20190 803.6603847
} 
the former sharing a border with Bulgaria and the latter with Romania. The outbreaks occurred close to the respective borders (Table 3 ).

\section{Greece}

ASF was confirmed in a backyard farm in the province of Kentriki Makedonika, distant from any international border. The source of the infection was reported to be undetermined (Table 3).

\section{Trends and challenges}

The two most important trends that can be identified for ASF in Europe are (1) endemic establishment in domestic pig and wild boar populations and (2) unpredictable long distance 'leaps' of the infection into new areas. The former trend in domestic pigs is linked to low biosecurity pig farming with practices that include allowing pigs to roam and feeding unsafe catering waste. This trend has played a relatively minor role in most of the affected EU states but appears to be important in the Danube Delta, judging from the number of outbreaks in backyard farms in Ukraine, Moldova, Romania and Bulgaria (Disease information-Immediate notifications 2005-2020). Stringent requirements for increased biosecurity as well as losses due to ASF resulted in a marked reduction of both smallholder pig farms and ASF in domestic pigs in Estonia (Nurmoja et al. 2018), but in less developed countries this is unlikely to happen. In 2005, large numbers of free-ranging pigs belonging to poor communities in the Eastern Cape province of South Africa were culled to eradicate an incursion of classical swine fever and a ban was placed on pig keeping unless good quality housing was available for the pigs. As this was unaffordable for the majority of pig keepers even after compensation for pigs culled, and they were heavily dependent upon their pigs to sustain their families, free-ranging pig husbandry was simply resumed (Madzimure et al. 2012).

The wild boar problem is unique. During the lengthy presence of ASF in the Iberian Peninsula wild boars played a minor role if any in the epidemic, although there was evidence of infection in wild boars in areas where domestic pigs were infected (Mur et al. 2012). The current situation is probably related to the high numbers of boars present in the affected states. The number of suspected instances of transboundary transmission amongst wild boars indicates meta-populations that move freely across borders.

The phenomenon of long-distance leaps of the virus is not unique to Europe by any means, but some spectacular examples have emerged in Europe in recent years. The first events occurred in Russia after ASF had been confined to the endemic southern area with gradual spread into the central area of European Russia until 2011, with the most distant affected locality being Arkhangelsk in the far north (Gogin et al. 2013). The eastward spread since 2017 that has affected localities in the Urals, Siberia and Far Eastern regions of Russia all suggest apparent long-distance transmission of the virus, but the Far East outbreaks could have had a more local origin in China. The other remarkable leaps that could only have been due to anthropogenic activity were the outbreaks in wild boars in Czech Republic and Belgium and the sudden appearance of ASF in western Poland. Given the amount of publicity that ASF in Europe has enjoyed, these actions can be considered surprising.

\section{Asia and Oceania}

Apart from ASF in the Transcaucasus at the junction of Europe and Asia, a report of ASF in wild boars in Iran close to the Armenian border (Rahimi et al. 2010) and the recent eastward extensions of ASF into Asian Russia, the Asian continent remained free of ASF until August 2018, when it was first reported in China. With half of the world's pig population, the threat of ASF in China had been a topic of concern in several publications previously (Costard et al. 2009; Anon. Preparing for the worst: African swine fever in China. Vet Rec 2017; Oura 2013; Vergne et al. 2017). When the first outbreak was announced on 3 August 2018 in north-eastern China it was accepted to be a major disaster for pig production in China (Wang et al. 2018) and a serious threat to other countries in Asia (Wang et al. 2019).

\section{China}

The first cases of ASF in China appeared in mid-June 2018 in a farm in Shenyang City, Liaoning Province, on the north-eastern coast of China. The pigs were reported to have been fed waste food, and 400 pigs died within a month after the first pigs began to show clinical signs usually observed in acute ASF (Zhou et al. 2018). Several other farms were affected and samples from dead pigs at one of the farms proved positive for a genotype II ASF virus highly related to those circulating in Eastern Europe (Zhou et al. 2018). The first available immediate notification to OIE reported outbreaks in Zheijiang Province (Table 4). By mid-August 2018 ASF outbreaks had been registered in four more eastern provinces (Disease information-Immediate notifications 2005-2020), all situated on or near the south-eastern coast of China. A commercial farm in Zheijiang Province and village pigs in Anhui and Jiangsu Provinces were affected and ASFpositive pigs were diagnosed at an abattoir in Henan Province (Disease information-Immediate notifications 2005-2020). By January 2019 ASF had spread across 25 of China's provinces (Zhou et al. 2019). Subsequently all of the mainland provinces as well as Hainan, an island 
province off the south coast, have reported ASF (Disease information-Immediate notifications 2005-2020).

In Hong Kong, ASF virus was detected in a condemned carcass of an imported pig in May 2019 and in three and one imported pigs that died after being brought to the same slaughterhouse in June and September 2019 respectively (Table 4). The autonomous enclave of Macao has not reported ASF.

Taiwan has reported detection of ASF virus in pork products brought into the country by travellers from China (Wang et al. 2019).

In spite of the rapid spread of ASF throughout China, it has only been reported a few times in free-living wild boars. One dead wild boar in Jilin Province (Table 4) tested positive for ASF virus in November 2018. Sequencing of the virus isolated from the boar indicated that it was identical to the Georgia 2007 virus that was also isolated from the outbreak in Irkutsk in 2017 (Kolbasov et al. 2018), while the viruses isolated from outbreaks in China had belonged to the more recently discovered variant that was circulating in eastern Europe including Russia (Li et al. 2019). The next cases in free-living wild boars involved nine dead boars found near a village in Shaanxi Province in 2019 and, in March 2020, two and five dead boars found at two locations in the same forestry district in Hubei Province (Disease information-Immediate notifications 2005-2020). An outbreak occurred in 77 out of 375 farmed wild boars in Heilongjiang Province in November 2018, the rest of which were destroyed, and another outbreak in captive wild boars occurred on a farm in Inner Mongolia in February 2019, in which all 222 wild boars were infected and 210 died; the remaining 12 were destroyed (Disease information-Immediate notifications 2005-2020).

In all of the outbreaks, quarantine and blockades were instituted and remaining pigs in the epidemiological unit were destroyed, resulting in the loss of an estimated half of the pig population and major disruption of pork production. The number of outbreaks apparently declined over time, but a disturbing number of the recent detections of infected pigs have occurred at checkpoints and abattoirs (Disease information-Immediate notifications 2005-2020), indicating that infected pigs are being moved in spite of restrictions.

Outbreaks of ASF in neighbouring countries were reported from early 2019 and are described in chronological order below.

\section{Mongolia}

With a total pig population of fewer than 30,000, Mongolia seemed an unlikely target for ASF. Nevertheless, it was the first of China's neighbours to report the disease. Outbreaks in domestic pigs occurred from 9 January to
6 February 2019 and were reported to be resolved on 27 March 2019 (Table 4). The outbreaks and control measures have been described (Heilmann et al. 2020). The pig farms involved were semi-intensive backyard farms and the source of the outbreaks was considered to be waste food fed to the pigs that contained imported infected pork products, supported by limited testing that discovered such products at food premises (Heilmann et al. 2020). No further outbreaks have occurred.

\section{Vietnam}

The event is reported to have started on 1 February 2019 (Table 4). Between that time and 18 August 20198501 outbreaks occurred, mainly in smallholder pigs, throughout the country (Disease information-Immediate notifications 2005-2020). No further outbreaks have been reported. The official estimate is that 21 per cent of the pig population was lost, but according to a report in Pig Progress the figure could be as high as 40 per cent and outbreaks continue to occur. ${ }^{10}$ The most likely source of infection was considered to be infected pork products from China, as the first outbreaks occurred in northern Vietnam close to China (Le et al. 2019).

\section{Cambodia}

After the first outbreak was reported (Table 4), six further outbreaks were reported in March and April 2019 in village pigs in the Rattanakiri district in the far north-east of Cambodia on the border with Vietnam, with spread to several villages (Disease information-Immediate notifications 2005-2020). The outbreaks were declared resolved in May 2019n (Disease information-Immediate notifications 2005-2020). However, in June 2019 six outbreaks were registered in village pigs in rather widely separated locations in the central southern region of the country (Disease information-Immediate notifications 2005-2020).

\section{Korea, North}

An outbreak on a cooperative farm with 99 pigs was reported on 23 May 2019; 77 pigs died and the rest were killed (Table 4). No further outbreaks have been reported. The farm was close to the north-western border with the Liaoning Province of China.

\section{Laos}

The first outbreaks were reported in village pigs in Sarvane province from 2 to 8 June 2019 (Table 4). Spread occurred to further provinces (Savannakhet, Sekong,

\footnotetext{
${ }^{10}$ https://www.pigprogress.net/Health/Articles/2020/4/ASF-accelerated-alot-in-Vietnams-pig-industry-575108E/.
} 
Khammuane, Attapeu, Champasak) from late June to September 2019 with 21 outbreaks in village pigs (Disease information-Immediate notifications 2005-2020). An outbreak occurred on a small commercial farm (110 pigs) in Vientiane Capital on 23 June 2019 (Table 4), followed by considerable spread around Vientiane and across the central north-eastern parts of the country in July to September (Disease information-Immediate notifications 2005-2020). The disease had become widespread, affecting mainly village pigs. In July and August 2019 the epidemic spread north-eastwards, with 15 outbreaks in village pigs in Huaphanh Province at localities throughout the province (Disease information-Immediate notifications 2005-2020). In August and September two and four each of an 'unidentified suid', most probably wild boar, were found in the forest in Huaphanh Province and were positive for ASF (Table 4). The last outbreak reported in village pigs in 2019 was at the beginning of October, and there have been no further reports since that time.

\section{Philippines}

The first outbreak cluster in village pigs was on 25 July 2019 in Rizal Province. In the cluster of 7 outbreaks 525 out of 536 pigs affected died of ASF and 7416 pigs were culled (Table 4). In September/October there were further outbreaks on Luzon Island in village pigs near the capital city and further to the north-east with culling of 5131 pigs (there were 59 deaths due to ASF). Further outbreaks occurred, mainly in Bulacan, Pampanga and Manila, in August to October, with 40,303 pigs culled (177 deaths due to ASF). Forty outbreaks from August to September resulted in culling of 74,967 pigs with 0 deaths reported. Outbreaks in September and October resulted in 17,763 pigs being culled, no deaths reported. The outbreaks continued until March 2020, with large numbers of pigs being culled and the infection apparently disseminated throughout Luzon Island (Disease informationImmediate notifications 2005-2020).

In January 2020 an outbreak occurred on Mindanao Island on the southern coast in backyard farms, with the deaths of 1000 pigs recorded (Table 4). Six more outbreaks occurred in backyard farms in February, with northward spread and 2261 deaths and 18,369 pigs destroyed. In another outbreak in February separately notified, the entire susceptible population of 2529 pigs was reported to have been destroyed (Disease information-Immediate notifications 2005-2020).

The first outbreak was suspected to have been caused by swill feeding, followed by illegal movement of pigs that were already sick being sold for a lower price. Subsequent spread was attributed to illegal movement of pigs, swill feeding and fomites (Disease information-Immediate notifications 2005-2020). The suspected source of the outbreaks was infected pork products brought into the Philippines by airline passengers as ASF viral genome was detected in several confiscated pork products. ${ }^{11}$

\section{Myanmar}

The first outbreak was in village pigs in Shan State on 1 August 2019, followed by another outbreak in village pigs in August, an outbreak in backyard pigs in August and another in backyard pigs in September (Table 4). All the outbreaks occurred in Shan State. No further outbreaks were reported in 2019. However, 2 outbreaks were reported in domestic pigs, again in Shan State, in February 2020 (Table 4).

\section{Indonesia}

After high mortality in pigs had occurred in September 2019, ASF was confirmed in November 2019 and 521 outbreaks of ASF were reported in backyard farms in 21 out of 33 districts in Sumatera Utara Province with a start date of 4 September 2019 (Table 4). Out of an estimated 1,228,951 pigs based on a 2018 census, 38,123 pigs died, with a case fatality rate of 100 per cent. The origin of the infection was not established but spread was attributed to movement of pigs, vehicles and fomites (Disease information-Immediate notifications 2005-2020).

\section{Timor-Leste}

The first outbreak cluster was reported on 9 September 2019 in backyard pigs (Table 4). One hundred outbreaks were reported on smallholder farms in the Dili Municipality, with the loss of 405 pigs that died of ASF. Based on a 2015 census, the number of smallholder pigs in the municipality is estimated to be 44,000 . In the follow-up report (13 March 2020) there were 26 outbreaks reported in 12 clusters between September and December 2019 that were scattered (Table 4); outbreak statistics were not provided in the summary. The devastating impact that ASF can have on the smallholder pig farmers who produce 100 per cent of the country's pigs, which are culturally as well as economically important, has been described (Smith et al. 2019). To date no further outbreaks have been reported.

\section{Korea, Republic (South)}

The introduction of infected pork products into South Korea by airline travellers from China was confirmed in August 2018 after surveillance of products entering the country was enhanced when China reported its

\footnotetext{
11 https://www.rappler.com/nation/233015-canned-goods-tainted-africanswine-fever-virus-clark-airport.
} 
first outbreaks of ASF (Kim et al. 2019). The first outbreak of ASF occurred more than a year later, on a commercial farm with 2450 pigs on 16 September 2019 in Gyeonggi-Do on the north-eastern border with North Korea (Kim et al. 2020a) (Table 4). Further outbreaks in pigs in the same area (including Incheon Metropolitan City) occurred in September and October 2019, after which no more domestic outbreaks were reported (Disease information-Immediate notifications 2005-2020; Kim et al. 2020a). However, from October 2019 to date, outbreaks in wild boars have been reported in GyeonggiDo and Gangwon-Do provinces, mostly in the Demilitarized Zone along the border with North Korea (Kim et al. $2020 \mathrm{~b})$. The highest number of outbreaks occurred in January 2020 (Jo and Gortázar 2020).

\section{Papua New Guinea}

ASF was confirmed in free-ranging village pigs four villages in Southern Highlands province in March 2020 in a population of 700 pigs, with the deaths of 396 out of 500 pigs affected (Table 4).

\section{India}

Unusual deaths among village pigs in north-eastern India commenced in the Arunachal Pradesh district in late January 2020, with outbreaks occurring in 11 villages in Arunachal Pradesh and Assam between January and April, with the deaths of 3701 pigs. The cause of the deaths was confirmed to be a genotype II ASF virus on 18 May 2020 (Table 4).

\section{Trends and challenges}

The great majority of outbreaks have occurred in backyard farms and village pigs, where implementation of biosecurity measures is usually inadequate or absent. An additional challenge for control in Timor-Leste and most recently Papua New Guinea is that pigs have important traditional and cultural roles, for example as ceremonial animals (Smith et al. 2019; Ayalew et al. 2011). This social and cultural importance of pigs is paralleled in some African countries but is usually not a consideration in modern animal disease control approaches.

The spread of ASF in Asia has been much more rapid in Asia than it has been in Europe. This is apparently due to movement of live pigs as well as pork. In China ASF detections at road barriers and abattoirs are considerably more frequently reported than elsewhere (Disease information-Immediate notifications 2005-2020). An additional phenomenon since ASF was detected in China were reports emanating from several countries, namely Australia, Japan, Northern Ireland, Philippines, South Korea, Taiwan and Thailand of infected pork products being introduced by airline passengers (Wang et al. 2019;
Kim et al. 2019; Ito et al. 2020; Jurado et al. 2019). In most cases the origin of the meat was specified to be travellers from China. Most of the reports either indicated that traces of the ASF virus genome were detected or did not specify the testing procedure, but attempts to culture the viruses detected in South Korea were not successful (Kim et al. 2019). The level of risk of introduction of ASF by the genomic material detected has yet to be determined.

\section{Perspectives on managing the current ASF situation}

The scale of the ASF situation that currently prevails is unprecedented. Given the diverse contexts in which the disease is present, a 'one size fits all', top-down approach can no longer be recommended. Eradication of ASF from areas outside Africa in the previous excursion was largely managed by massive eradication programmes carried out by countries that were either at least relatively wellresourced or by large-scale international funding. The countries currently affected include lower income countries and the major crises currently demanding international funding, most of which have direct public health impacts, suggest that unlimited funds will not be available to manage ASF. This may not be a bad thing, as in settings where numerous owners keep a few pigs to keep abject poverty at bay, drastic control measures may have far worse effects than the disease itself, and a more measured approach can provide sufficient mitigation and even result in ultimate eradication.

The key to avoiding major and costly ASF epidemics is preventing pigs from becoming infected, and in the absence of a vaccine this depends on the implementation of biosecurity measures based on knowing the epidemiological risks. It also involves risk-based surveillance to avoid introduction of the virus into new countries and to ensure rapid detection of outbreaks to enable a timely response.

\section{Managing ASF to protect commercial pig production}

Although some large commercial farms in several countries have suffered serious losses to ASF, the relatively low incidence of outbreaks in the commercial sector in many of the countries affected indicates that good biosecurity does prevent the disease. However, especially in areas where the risk of ASF is very high, for example where the virus is circulating in wild boars or poorly controlled populations of domestic pigs, compartmentalisation of commercial pig farming enterprises can be strongly recommended. ${ }^{12}$ As the ASF virus is not airborne over distances greater than a few metres in a closed housing system (Wilkinson et al. 1977; de Carvalho Ferreira et al.

\footnotetext{
${ }^{12}$ OIE Terrestrial Animal Health Code Chapters 4.4 and 4.5.
} 
2013) and to date no important role for flying arthropods as mechanical vectors has been demonstrated (Plowright et al. 1994; Forth et al. 2018; Tummeleht et al. 2020), the introduction of ASF into farms invariably involves human activity that can be prevented if biosecurity is strictly implemented.

\section{Managing ASF in semi- and non-commercial pig production}

The challenges posed for implementation of biosecurity in smallholder, backyard and traditionally kept village pigs are well known, while finding the answers to the problems is a work in progress. Awareness creation and moving towards modernisation of production are usually recommended but the latter is not achievable without adequate support and the former may have the opposite effect to that intended (Chenais et al. 2017; Chenais et al. 2019). The main incentive for improving pig husbandry would be profit, which is only likely if easily accessible markets are available. A thorough understanding of the social networks and pig value chains in which pigs and pork are traded will help to involve producers, traders and other value chain actors to work with animal health practitioners to find situation-specific, socially acceptable and affordable ways to mitigate the risk of ASF.

\section{Managing ASF in free-living wild boar or feral pig populations}

Before the incursion of ASF into the Baltic States and Poland, it was generally accepted that ASF in wild boar populations was self-limiting (Mur et al. 2016; Gogin et al. 2013; Mur et al. 2012), but it was also considered likely to be maintained in sufficiently large populations of wild boars (Gogin et al. 2013). In Belgium and Czech Republic it was possible to eradicate the infection (Marcon et al. 2020), which in both cases could be restricted to a limited area. However, Estonia and Latvia, where the whole countries were infected, the combination of surveillance for and burial of wild boar carcasses and population reduction due both to ASF and to increased hunting pressure has resulted in a demonstrable decline in virus circulation (Schulz et al. 2019; Olsevskis et al. 2020).

\section{Managing ASF at the interface with the classic sylvatic cycle}

The only way to prevent ASF at the interface with the classic sylvatic cycle is to ensure good separation of the domestic pigs. For commercial farms this has been successfully achieved over many decades, but where smallscale pig farming occurs at the interface the challenge will be similar to those experienced in managing the risks that are present in that farming sector.

\section{Managing outbreaks of ASF}

How outbreaks of ASF are managed will depend on the resources available to the national veterinary services, the legislation governing outbreak management, and the contribution of the pig sector to national income. Countries with a large export trade in pigs and pork would be motivated to get rid of ASF as rapidly as possible, whereas countries that do not export pork will be more likely to take a less drastic approach. Whatever approach is taken, the cooperation of the pig producers and other pig value chain actors is paramount and the approach should be acceptable not only to them but to the public at large. It must also be feasible in terms of logistics including appropriate disposal of dead pigs, available financial, human and other resources, and animal welfare. It is increasingly recognised that various options are available for managing an animal disease emergency, and it is important that the measures should not cause more damage than the disease itself (Rubira 2007).

\section{Managing ASF with a vaccine}

A safe and effective vaccine would have immense advantages for the management of ASF, but the operative words are safe and effective, and for many countries one would need to add affordable. Many of the affected countries are tropical, so not having rigorous cold chain requirements would be an additional prerequisite.

Although efforts to find a vaccine are ongoing and progress is reported to be promising, a word of caution has been sounded about potentially unsafe vaccines based on previous unfortunate experiences with insufficiently attenuated viruses (Gavier-Widén et al. 2020). It should furthermore be remembered that a good vaccine is an important tool in the toolbox of disease management, but will never replace the need to implement good biosecurity in pig farming operations.

\section{Conclusion}

Two main trends have been identified that characterise the current ASF situation globally: endemic establishment in free-living wild pig populations and in domestic pigs reared under hazardous husbandry conditions, and persistent high-risk activities on the part of humans.

The tendency for ASF to become endemic in areas where small-scale pig production under conditions of inadequate or no biosecurity predominates is common to Africa, Asia and Eastern Europe. In these settings conventional approaches to ASF control are likely to fail due to lack of producer cooperation and the realities that create this reluctance. The challenge is to provide the incentives and support required to enable subsistence pig farmers to invest in improving biosecurity, because prohibiting non-commercial pig production can only work 
if is not essential for survival. In a number of African countries, particularly in West Africa in areas that are not suitable for cattle production, as well as in Timor-Leste, Papua New Guinea and possibly other countries in the Asian-Pacific region pigs have cultural and social as well as economic importance, and this further complicates control, which in order to be acceptable must respect the customs and beliefs of the pig keepers.

While maintenance of ASF virus by African wild suids that are tolerant to the infection is not a major problem as they are not efficient at spreading the virus, the predominant involvement of wild boars in Europe has created a highly challenging situation. There is no easy recipe for managing ASF in free-living susceptible pig populations, particularly when they include meta-populations that extend across international borders. However, there is evidence that the combination of surveillance based largely on finding and safely disposing of dead wild boars and wild boar population reduction have had positive results in two of the affected countries. Fortunately, with the exception of South Korea the involvement of wild boars in Asia so far has been insignificant.

Risky practices that lead to the spread of ASF are not confined to the informal pig sector, where they are largely responsible for local spread within the sector. Rapid spread over large areas as occurred in China as well as long-distance 'leaps' that have infected pigs or wild boars as happened in Russia, Poland, Czech Republic and Belgium can only be ascribed to human activities that are likely financially motivated. Persuading humans to change their behaviour, whether it results from ignorance, carelessness or the drive for profit is the greatest challenge of all.

Delimitation of infected areas and stamping out all the pigs within a defined radius is the traditional approach to controlling and eradicating outbreaks of ASF. Compliance is usually obtained by paying reasonable compensation to farmers for healthy pigs culled. The success of the approach depends on the resources available to carry out the measures as quickly as possible and to enforce quarantine and movement control, with the latter expected to involve checkpoints on major roads. It also depends on knowing the number and location of all the pigs involved. This information is seldom reliable in the informal pig sector. If a quick and efficient culling operation cannot be guaranteed, a more measured approach such as modified culling in agreement with the owners is more likely to be successful.

\section{Abbreviations}

ASF: African swine fever; AU-IBAR: African Union-Interafrican Bureau for Animal Resources; CAR: Central African Republic; DRC: Democratic Republic of Congo;
FAO: Food and Agriculture Organization of the United Nations; OIE: World Organisation for Animal Health.

\section{Acknowledgements}

Not applicable.

\section{Authors' contributions}

MLP conceived and wrote the manuscript. The author read and approved the final manuscript.

\section{Authors' information}

MLP is a veterinarian attached to the Department of Veterinary Tropical Diseases at the University of Pretoria, South Africa. She has a strong interest in the epidemiology and control of diseases of pigs with a strong focus on African and classical swine fever and on how to manage them in resourcepoor settings through practical and affordable risk management in small-scale production systems and the value chains available to them.

\section{Funding}

Not applicable.

\section{Availability of data and materials}

The datasets analysed during the current study are available in the OIE WAHIS repository at https://www.oie.int/wahis_2/public/wahid.php/Wahidhome/ Home.

Ethics approval and consent to participate

Not applicable.

\section{Consent for publication}

Not applicable.

\section{Competing interests}

There are no competing interests.

Received: 7 May 2020 Accepted: 23 July 2020

Published online: 05 August 2020

References

Abworo EO, Onzere C, Oluoch-Amimo J, Riitho V, Mwangi W, Davies J, et al. Detection of African swine fever virus in the tissues of asymptomatic pigs in smallholder farming systems along the Kenya-Uganda border: implications for transmission and surveillance in endemic areas in East Africa. J Gen Virol. 2017. https://doi.org/10.1099/jgv.0.000848.

Achenbach JE, Gallardo C, Nieto-Pelegrin E, Rivera-Arroyo B, Degefa-Negi T, Arias $M$, et al. Identification of a new genotype of African swine fever virus in domestic pigs from Ethiopia. Transbound Emerg Dis. 2017. https ://doi.org/10.1111/tbed.12511.

Alexander FC. Experiences with African swine fever in Haiti. AnnNY Acad Sci. 1992;653:251-6.

Andriamanivo HR, Randriamananjara D, Ralalarison RA, Nomenjanahary LA Razafindraibe NP, Andria-Mananjara ED, et al. How could an African swine fever outbreak evolve in an enzootic context? The case of Imerintrsiatosika, Madagascar in 2015. PLoS ONE. 2019. https://doi. org/10.1371/journal.pone.0221928.

Anon. Preparing for the worst: African swine fever in China. Vet Rec 2017;181:115-6.

Asambe A, Sackey AKB, Tekdek LB. Prevalence of African swine fever virus and classical swine fever virus antibodies in pigs in Benue State, Nigeria. Trop Anim Health Prod. 2017. https://doi.org/10.1007/s1125 0-017-1461-y.

Atuhaire DK, Afayoa M, Ochwo S, Mwesigwa S, Okuni JB, Olaho-Mukani W, et al. Molecular characterization and phylogenetic study of African swine fever isolates from recent outbreaks in Uganda (2010-2013). Virol J. 2013;10:247.

AU-IBAR. Panafrican Animal Health Yearbook 2011. Nairobi: African UnionInterafrican Bureau for Animal Resources; 2011. . 
Ayalew W, Danbaro G, Dom M, Amben S, Besari F, Moran C, et al. Genetic and cultural significance of indigenous pigs in Papua New Guinea and their phenotypic characteristics. Anim Genet Resour. 2011. https://doi. org/10.1017/S2078633611000026.

Badaev FA, Rudobel'skii EV, Chebelev SF, Kiselev AV, Zakharov VM, Baibikov TZ. [Evaluation of role of local indigenous pigs as a reservoir of African swine fever in Zaire]. Vestnik Sel'skokhozyaistvennoi Nauki (Moskva). 1992; p. 131-3.

Barasona JA, Gallardo C, Cadenas-Fernández E, Jurado C, Rivera B, RodríguezBertos A, et al. First oral vaccination of Eurasian wild boar against African swine fever virus genotype II. Front Vet Sci. 2019. https://doi. org/10.3389/fvets.2019.00137.

Bastos ADS, Penrith M-L, Crucière C, Edrich JL, Hutchings G, Roger F, et al. Genotyping field strains of African swine fever virus by partial p72 gene characterisation. Arch Virol. 2003. https://doi.org/10.1007/s0070 5-002-0946-8.

Beltran Alcrudo D, Lubroth J, Depner K, De la Rocque S. African swine fever in the Caucasus. EMPRES Watch, April 2008. Rome: Food and Agriculture Organization of the United Nations. 2008. http://www.fao.org/3/a-aj214 e.pdf. Accessed 27 April 2020.

Bidjeh K, Ban-Bo BA, Mopate Logtene Y. Factors contributing to the introduction and the spread of African swine fever in Chad. Int J Curr Microbiol Appl. Sci. 2015;4:607-13.

Biront P, Castryck F, Leunen J. An epizootic of African swine fever in Belgium and its eradication. Vet Rec. 1987;120:432-4.

Bisimwa NP, Wasso SD, Ntakundi MT, Bwihangane TA, Bisimwwa BE, Mushagalusa NG, et al. Evidence of African swine fever virus in pigs slaughtered at Muhanzi Municipal Abattoir in Bukavu City, Eastern of Democratic Republic of Congo. Int J Microbiol Biotechnol. 2019. https ://doi.org/10.11648/j.jmb.20190401.11.

Boinas FS, Hutchings GH, Dixon LK, Wilkinson PJ. Characterization of pathogenic and non-pathogenic African swine fever virus isolates from Ornithodoros erraticus inhabiting pig premises in Portugal. J Gen Virol. 2004. https://doi.org/10.1099/vir.0.80058-0.

Brown A-A, Penrith M-L, Fasina FO, Beltran-Alcrudo D. The African swine fever outbreak in West Africa, 1996-2002. Transbound Emerg Dis. 2018. https ://doi.org/10.1111/tbed.12673.

Cappai S, Rolesu S, Coccollone A, Laddomada A, Loi F. Evaluation of biological and socio-economic factors related to persistence of African swine fever in Sardinia. Prev Vet Med. 2018. https://doi.org/10.1016/j. prevetmed.2018.01.004.

Chang'a JS, Mayenga C, Settypalli TBK, Achenbach JE, Mwanandota JJ, Magidanga B, et al. Symptomatic and aymptomatic cases of African swine fever in Tanzania. Transbound Emerg Dis. 2019. https://doi. org/10.1111/tbed.13296.

Chenais E, Boqvist S, Sternberg-Lewerin S, Emanuelson U, Ouma E, Dione $M$, et al. Knowledge, attitudes and practices related to African swine fever within smallholder pig production in northern Uganda. Transbound Emerg Dis. 2017. https://doi.org/10.1111/tbed.12347.

Chenais E, Sternberg-Lewerin S, Boqvist S, Ståhl K, Alike S, Nokorach B, et al. Smallholders' perceptions on biosecurity and disease control in relation to African swine fever in an endemically infected area in Northern Uganda. BMC Vet Res. 2019. https://doi.org/10.1186/s1291 7-019-2005-7.

Contini A, Cossu P, Rutili D, Firinu A. African swine fever in Sardinia. In: Wilkinson PJ, editor. African Swine Fever. EUR 8466 EN. Luxembourg: Commission of the European Communities; 1983. p. 1-6.

Costard S, Wieland B, de Glanville W, Jori F, Rowlands E, Vosloo W, et al. African swine fever: how can global spread be prevented? Philos Trans $R$ Soc B. 2009a. https://doi.org/10.1098/rstb.2009.0098.

Costard S, Porphyre V, Messad S, Rakotondrahanta S, Vidon H, Roger F, et al. Multivariate analysis of management and biosecurity practices in smallholder pig farms in Madagascar. Prev Vet Med. 2009b. https:// doi.org/10.1016/j.prevetmed.2009.08.010.

Couacy-Hymann E, Kouakou KV, Achenbach JE, Kouadio L, Koffi YM, Godji $H$, et al. Re-emergence of genotype I of African swine fever virus in Ivory Coast. Transbound Emerg Dis. 2019. https://doi.org/10.1111/ tbed.13098.

Cwynar P, Stojkov J, Wlazlak K. African swine fever status in Europe. Viruses. 2019. https://doi.org/10.3390/v11040310.laddomada. de Abreu EF, Valadão FB, Serra JJB, Mário R, Montenegro A. Peste suína africana em Moçambique. Anais dos Serviços Veterinárias de Moçambique. 1962;8:105-23.

de Carvalho Ferreira HC, Weesendorp E, Quak S, Stegeman JA, Loeffen WLA. Quantification of airborne African swine fever virus after experimental infection. Vet Microbiol. 2013. https://doi.org/10.1016/j.vetmi c.2013.03.007.

de Jong YA, Cumming D, d'Huart J, Butynski T. Phacochoerus africanus. The IUCN List of Threatened Species 2016: e.T41768A109669842. International Union for Conservation of Natural Resources. 2016; https://doi. org/10.2305/iucn.uk.2016-2.rlts.t41768a44140445.en.

De Kock G, Robinson EM, Keppel JJG. Swine fever in South Africa. Onderstepoort J Vet Sci Anim Ind. 1940;14:31-93.

Depner K, Gortazar C, Guberti V, Masiulis M, More S, Olševskis E, et al. Epidemiological analyses of African swine fever in the Baltic States and Poland. EFSA J. 2017. https://doi.org/10.2903/j.efsa.2017.5068.

Dione M, Ouma E, Opio F, Kawuma B, Pezo D. Qualitative analysis of the risks and practices associated with the spread of African swine fever within the smallholder pig value chains in Uganda. Prev Vet Med. 2016. https://doi.org/10.1016/.jprevetmed.2016.11.001.

Dione MM, Akol J, Roesel K, Kungu J, Ouma EA, Wieland B. Risk factors for African swine fever in smallholder pig production systems in Uganda. Transbound Emerg Dis. 2017. https://doi.org/10.1111/tbed.12542.

Ekue NF, Wilkinson PJ. Absence of Ornithodoros moubata, the vector of African swine fever virus, from the main pig producing area of Cameroon. Trop Anim Health Prod. 1990;22:127-31.

El Hicheri K, Gomez-Tejedor C, Penrith M-L, Davies G, Douati A, Edoukou G, et al. L'épizootie de peste porcine africaine de 1996 en Côte d'Ivoire. Rev sci tech Off int Epiz. 1998;17:660-73.

Etter EMC, Seck I, Grosbois V, Jori F, Blanco E, Vial L, et al. Seroprevalence of African swine fever in Senegal, 2006. Emerg Infect Dis. 2011. https://doi. org/10.3201/eid1701.100896.

FAO. Secteur Porcin Burkina Faso. Revues nationales de l'élevage de la division de la production et de la santé animales de la FAO. No. 1. Rome: Food and Agriculture Organization of the United Nations; 2012.

Fasina FO, Agbaje M, Ajani FL, Talabi OA, Lazarus DD, Gallardo C, et al. Risk factors for farm-level African swine fever infection in major pigproducing areas in Nigeria, 1997-2011. Prev Vet Med. 2012. https://doi. org/10.1016/j.prevetmed.2012.05.011.

Fois F, Culurgioni J, Cappai S, Mereu Pira P, Toma L, Rolesu S, et al. An overview on Sardinia's soft ticks (Ixodida: argasidae). Exp Appl Acarol. 2016. https ://doi.org/10.1007/s10493-016-0029-2.

Forth JH, Amendt J, Blome S, Depner K, Kampen H. Evaluation of blowfly larvae (Diptera: Calliphoridae) as possible reservoirs and mechanical vectors of African swine fever virus. Transb Emerg Dis. 2018. https://doi. org/10.1111/tbed.12688.

Gago da Câmara NJ. História da peste suína em Angola. Pecuária. 1932;1933(1):25-40.

Gallardo C, Fernández-Pinero J, Pelayo V, Gazaev I, Markowska-Daniel I, Pridotkas $G$, et al. Genetic variation among African swine fever genotype II viruses Eastern and Central Europe. Emerg Infect Dis. 2014. https://doi. org/10.3209/eid2009.140554.

Garigliany M, Desmecht D, Tignon M, Cassart D, Lesenfan C, Paternostre J, et al. Phylogeographic analysis of African swine fever virus, Western Europe, 2018. Emerg Infect Dis. 2019. https://doi.org/10.3201/eid2501.181535.

Gavier-Widén D, Ståhl K, Dixon L. No hasty solutions for African swine fever. Science. 2020. https://doi.org/10.1126/science.aaz8590.

Geertsma PJ, Mpofu D, Walters J. Investigation and control of an outbreak of African swine fever in the Gauteng Province in 2012. Proceedings of the $10^{\text {th }}$ Annual Congress of the Southern African Society for Veterinary Epidemiology and Preventive Medicine 1-3 August 2012, Farm Inn, South Africa, 2012. p. 17-21.

Gilliaux G, Garigliany M, Licoppe A, Paternostre J, Lesenfants C, Linden A, et al. Newly emerged African swine fever virus Belgium/Etalle/wb/2018: complete genomic sequence and comparative analysis with reference p72 genotype II strains. Transbound Emerg Dis. 2019. https://doi. org/10.1111/tbed.13302.

Gogin A, Gerasimov V, Malogolovkin A, Kolbasov D. African swine fever in the North Caucasus region and the Russian Federation in the years 20072012. Virus Res. 2013. https://doi.org/10.1016/j.virusres.2012.12.007. 
Goller KV, Malogolovkin AS, Katorkin S, Kolbasov D, Titov I, Höper D, et al. Tandem repeat insertion in African swine fever virus, Russia, 2012. Emerg Infect Dis. 2015. https://doi.org/10.3201/eid2104.141792.

Haresnape JM, Wilkinson PJ, Mellor PS. Isolation of African swine fever virus from ticks of the Ornithodoros moubata complex (Ixodoidea: argasidae) collected within the African swine fever enzootic area of Malawi. Epidemiol Infect. 1988;101:173-85.

Heilmann M, Lkhagvasuren A, Adyasuren T, Khishgee B, Bold B, Ankhanbaatar $\mathrm{U}$, et al. African swine fever in Mongolia: course of the outbreak and applied control measures. Vet Sci. 2020. https://doi.org/10.3390/vetsc i7010024.

Herm R, Tummeleht L, Jürison M, Vilem A, Viltrop A. Trace amounts of African swine fever virus DNA detected in insects collected from an infected pig farm in Estonia. Vet Med Sci. 2020. https://doi.org/10.1002/ vms3.200.

Iglesias I, Rodríguez A, Feliziani F, Rolesu S, de la Torre A. Spatio-temporal analysis of African swine fever in Sardinia (2012-2014): trends in domestic pigs and wild boar. Transbound Emerg Dis. 2017. https://doi. org/10.1111/tbed.12408.

Ito S, Jurado C, Sánchez-Vizcaíno JM, Norikazu I. Quantitative risk assessment of African swine fever introduction to Japan via pork products brought in air passengers'luggage. Transbound Emerg Dis. 2020. https://doi. org/10.1111/tbed.13414.

Janse van Rensburg L, Etter E, Heath L, Penrith M-L, van Heerden J. Understanding African swine fever outbreaks in domestic pigs in a sylvatic endemic area: the case of the South African controlled area between 1977-2017. Transbound Emerg Dis. 2020a. https://doi.org/10.1111/ tbed.13632.

Janse van Rensburg L, van Heerden J, Penrith M-L, Heath LE, Rametse T, Etter E. Investigation of African swine fever outbreaks in pigs outside the controlled areas of South Africa, 2012-2017. J S Afr Vet Assoc. 2020b. https://doi.org/10.4102/jsava.v91i0.1997.

Jo Y-S, Gortázar C. African swine fever in wild boar, South Korea, 2019. Transbound Emerg Dis. 2020. https://doi.org/10.1111/tbed.13532.

Jori F, Vial L, Penrith ML PèrezSánchez R, Etter E, Albina E, et al. Review of the sylvatic cycle of African swine fever in sub-Saharan Africa and the Indian Ocean. Virus Res. 2013. https://doi.org/10.1016/j.virus res.2012.10.005

Jurado C, Mur L, Pérez Aguirreburualde MS, Cadenas-Fernández E, MartínezLópez B, Sánchez-Vizcaíno JM, et al. Risk of African swine fever introduction into the United States through smuggling of pork in air passenger luggage. Sci Rep. 2019. https://doi.org/10.1038/s41598-019-50403-w.

Katale BZ, Fyumagwa RD, Mdaki ML, Hoare R. Prevalence of African swine fever virus in warthogs in the Serengeti ecosystem, Tanzania. Res Opin Anim Vet Sci. 2012;2:339-43.

Kim H-J, Lee MJ, Lee SK, Kim DY, Seo SJ, Kang HE, et al. African swine fever virus in pork brought into South Korea by travelers from China, August 2018. Emerg Infect Dis. 2019. https://doi.org/10.3201/eid2506.181684.

Kim H-J, Cho K-H, Lee S-K, Kim D-A, Nah J-J, Kim H-J, et al. Outbreak of African swine fever in South Korea, 2019. Transbound Emerg Dis. 2020a. https:// doi.org/10.1111/tbed.13483.

Kim S-H, Kim J, Son K, Choi Y, Jeong H-S, Kim Y-K, et al. Wild boar harbouring African swine fever virus in the demilitarized zone in South Korea, 2019. Emerg Microbes Infect. 2020b. https://doi.org/10.1080/22221 751.2020 .1738904$.

Kolbasov D, Titov I, Tsybanov S, Gogin A, Malagolovkin A. African swine fever virus, Siberia, 2017. Emerg Infect Dis. 2018. https://doi.org/10.3201/ eid2009.140554.

Korennoy FI, Gulenkin VM, Gogin AE, Vergne T, Karaulov AK. Estimating the basic reproductive number for African swine fever using the Ukrainian historical epidemic of 1977. Transbound Emerg Dis. 2017. https://doi. org/10.1111/tbed.12583.

Kouakou KV, Michaud V, Biego HG, Gnabro HPG, Kouakou AV, Mossoun AM, et al. African and classical swine fever situation in Ivory-Coast and neighbouring countries, 2008-2013. Acta Trop. 2017. https://doi. org/10.1016/j.actatropica.2016.10.027.

Koussou MO, Dutuertre G. Les facteurs de competitivité de la filière porcine dans la Bassin du Logone. Koussou_Duteurtre_2002.pdf, 2002; http:// pigtrop.cirad.fr/subjects/socio_economy_in_pig_production_sector/ filiere_porcine_au_nord_cameroun. Accessed 18 July 2015.
Laddomada A, Patta C, Oggiano A, Caccia A, Ruiu A, Cossu P, et al. Epidemiology of classical swine fever in Sardinia: a serological survey of wild boar and comparison with African swine fever. Vet Rec. 1994. https://doi. org/10.1136/vr.134.8.183.

Laddomada A, Rolesu S, Loi F, Cappai S, Oggiano A, Madrau MP, et al. Surveillance and control of African swine fever in free-ranging pigs in Sardinia. Transbound Emerg Dis. 2019. https://doi.org/10.1111/tbed.13138.

Le VP, Jeong DG, Yoon SW, Kwon H-M, Trinh TBN, Nguyen TL, et al. Outbreak of African swine fever, Vietnam, 2019. Emerg Infect Dis. 2019. https://doi. org/10.3201/eid2507.190303.

Li X, Tian K. African swine fever in China. Vet Rec. 2018. https://doi.org/10.1136/ vr.k3774.

Li L, Wang Q, Ge S, Liu Y, Liu C, Liu F, et al. Infection of African swine fever in wild boar, China, 2018. Transbound Emerg Dis. 2019. https://doi. org/10.1111/tbed.13114.

Lichoti JK, Davies J, Kitala PM, Githigia SM, Okoth E, Maru Y, et al. Social network analysis provides insights into African swine fever epidemiology. Prev Vet Med. 2016. https://doi.org/10.1016/j.prevetmed.2016.01.019.

Linden A, Licoppe A, Volpe R, Paternostre J, Lesenfants C, Cassart D, et al. African swine fever virus hits north-western Europe. Transbound Emerg Dis. 2018. https://doi.org/10.1111/tbed.13047.

Lubisi BA, Bastos ADS, Dwarka RM, Vosloo W. Molecular epidemiology of African swine fever in East Africa. Arch Virol. 2005. https://doi.org/10.1007/ s00705-005-0602-1.

Lubisi BA, Dwarka RM, Meenowa D, Jaumally R. An investigation into the first outbreak of African swine fever in the Republic of Mauritius. Transbound Emerg Dis. 2009. https://doi.org/10.111 1/j.1865-1682.2009.01078.x.

Luther NJ, Majiyagbe KA, Shamaki D, Lombin LH, Antiabong JF, Bitrus Y, et al. Detection of African swine fever virus genomic DNA in a Nigerian red river hog (Potamochoerus porcus). Vet Rec. 2007a. https://doi. org/10.1136/vr.160.2.58.

Luther NJ, Udeama PG, Majiyagbe KA, Shamaki D, Antiabong JF, Bitrus Y, et al. Polymerase chain reaction (PCR) detection of the genome of African swine fever virus (ASFV) from natural infection in a Nigerian baby warthog (Phacochoerus aethiopicus). Niger Vet J. 2007b;28:63-7.

Mačiulskis P, Masiulis M, Pridotkas G, Buitkuvienè J, Jurgelevičius V, Jacevičienė I, et al. The African swine fever epidemic in Lithuania (2014-2018). Vet Sci. 2020. https://doi.org/10.3390/vetsci7010015.

Madeira S, Pinheiro C, Ribeiro R, Boinas F. Implementation of a contingency plan for the control of an African swine fever sporadic outbreak in Portugal. XVII International Congress on Animal Hygiene 2015. Kosice, Slovakia. 2015; p. 149-151. [152].

Madzimure J, Zander KK, Dzama K, Chimonyo M. Farmer perceptions of classical swine fever outbreak in communal pig production systems of South Africa. Afr J Agric Res. 2012. https://doi.org/10.5897/AJAR12.710.

Magadla NR, Vosloo W, Heath L, Gummow B. The African swine fever control zone in South Africa and its current relevance. Onderstepoort J Vet Res. 2016. https://doi.org/10.4102/ojvr.v83i1.1034.

Mannelli A, Sotgia S, Patta C, Sarria A, Madrau P, Sanna L, et al. Effect of husbandry methods on seropositivity to African swine fever virus in Sardinian swine herds. Prev Vet Med. 1997. https://doi.org/10.1016/ s0167-5877(97)00026-3.

Marcon A, Linden A, Satran P, Gervasi V, Licoppe A, Guberti V. Ro estimation for the African swine fever epidemics in wild boar of Czech Republic and Belgium. Vet Sci. 2020. https://doi.org/10.3390/vetsci7010002.

Mendes AM. A história da peste suína africana em Angola. Rev Port Ciênc Vet. 1994;89:110-20.

Michaud V, Randriamparany T, Albina E. Comprehensive phylogenetic reconstructions of African swine fever virus: proposal for a new classification and dating of the virus. PLOS ONE. 2013. https://doi.org/10.1371/journ al.pone.0069662.

Montgomery RE. On a form of swine fever occurring in British East Africa (Kenya Colony). J Comp Pathol. 1921;34:159-91, 243-62.

Moura JA, McManus C, Bernal FEM, de Melo CB. An analysis of the 1978 African swine fever outbreak in Brazil and its eradication. Rev sci tech Off Int Epiz. 1978;29:549-63.

Mulumba-Mfumu LK, Saegerman C, Dixon LK, Madimba KC, Kazadi E, Mukalakata ND, et al. African swine fever: update on Eastern, Central and Southern Africa. Transbound Emerg Dis. 2019. https://doi. org/10.1111/tbed.13187. 
Mur L, Boadella M, Martínez-López B, Gallardo C, Gortazar C, Sánchez-Vizcaíno $J M$. Monitoring of African swine fever in the wild boar population of the most recent endemic area of Spain. Transbound Emerg Dis. 2012. https ://doi.org/10.1111/j.1865-1682.2012.01308.x.

Mur L, Atzeni M, Martínez-López B, Feliziani F, Rolesu S, Sánchez-Vizcaíno JM. Thirty-five year presence of African swine fever in Sardinia: history, evolution and risk factors for disease maintenance. Transbound Emerg Dis. 2016. https://doi.org/10.1111/tbed.12264.

Mur L, Iscaro C, Cocco M, Jurado C, Rolesu S, De Mia GM, et al. Serological surveys and direct field searching reaffirm the absence of Ornithodoros erraticus ticks role in African swine fever cycle in Sardinia. Transbound Emerg Dis. 2017. https://doi.org/10.1111/tbed.12485.

Mur L, Sánchez-Vizcaíno JM, Fernández-Carrión E, Jurado C, Rolesu S, et al. Understanding African swine fever infection dynamics in Sardinia using a spatially explicit transmission model in domestic pig farms. Transbound Emerg Dis. 2018. https://doi.org/10.1111/tbed.12636.

Nana-Nukechap MF, Gibbs EPJ. Socioeconomic effects of African swine fever in Cameroon. Trop Anim Health Prod. 1985;17:183-4.

Negrin RES. Development in Cuba of a programme for the eradication of African swine fever in 1980. In: Wilkinson PJ, editor. African Swine Fever. EUR 8466 EN. Luxembourg: Commission of the European Communities. 1983; p. 36-41.

Nurmoja I, Schulz K, Staubach C, Sauter-Louis C, Depner K, Conraths FJ, Viltrop A. Development of African swine fever epidemic among wild boar in Estonia - two different areas in the epidemiological focus. Sci Rep. 2017. https://doi.org/10.1038/s41598-017-12952-w.

Nurmoja I, Motus K, Kristian M, Niine T, Schulz K, Depner K, et al. Epidemiological analysis of the 2015-2017 African swine fever outbreaks in Estonia. Prev Vet Med. 2018. https://doi.org/10.1016/j.prevetmed.2018.10.001.

OIE-WAHIS. Disease information-Immediate notifications, 2005-2020. https ://www.oie.int/wahis_2/public/wahid.php/Diseaseinformation/ Immsummary.

Oliver W, Brisbin I. Introduced and feral pigs: Problems, policies and priorities. The Eurasian Wild Pig. In: Oliver, WLB, editor. Pigs, Peccaries and Hippos Status Survey and Action Plan. Gland: IUCN/SSC. 1993; p. 269-286.

Olsevskis E, Guberti V, Serzants M, Westergaard J, Gallardo C, Rodza I, et al. African swine fever virus introduction into the EU in 2014: experience of Latvia. Res Vet Sci. 2014. https://doi.org/10.1016/j.rvsc2016.01.006.

Olsevskis E, Schulz K, Staubach C, Serzants M, Lamberga K, Pule D, et al. African swine fever in Latvian wild boar-a step closer to elimination. Transb Emerg Dis. 2020. https://doi.org/10.1111/tbed.13611.

Ordás A, Sánchez-Botija C, Bruyel V, Olias J. African swine fever. The current situation in Spain. In: Wilkinson PJ, editor. African Swine Fever. EUR 8466 EN. Luxembourg: Commission of the European Communities; 1983. p. 7-11.

Oura C. African swine fever: on the move and dangerous. Vet Rec. 2013. https ://doi.org/10.1136/vr.f5327.

Pautenius A, Grigas J, Pileviciene S, Zagrabskaite R, Buitkuviene J, Pridotkas G, et al. Prevalence and spatio-temporal distribution of African swine fever in Lithuania, 2014-2017. Virol J. 2018. https://doi.org/10.1186/s1298 5-018-1090-8

Pejsak Z, Truszczynski M, Niemczuk K, Kozak E, Markowska-Daniel I. Epidemiology of African swine fever in Poland since the detection of the first case. Pol J Vet Sci. 2014. https://doi.org/10.2478/pjvs-2014-0097.

Pejsak Z, Niemczuk K, Frant M, Mazur M, PomorskaMól M, ZietekBarszcz A, et al. Four years of African swine fever in Poland New insights into epidemiology and prognosis of future disease spread. Pol J Vet Sci. 2018. https:// doi.org/10.24425/pjvs.2018.125598.

Penrith M-L, Lopes Pereira C, da Silva MMR, Quembo C, Nhamusso A, Banze J. Overview of African swine fever in Mozambique: risk factors and potential for control. Onderstepoort J Vet Res. 2007;74:149-60.

Penrith M-L, Vosloo W, Jori F, Bastos ADS. African swine fever virus eradication in Africa. Virus Res. 2013. https://doi.org/10.1111/j.virusres.2012.10.011.

Penrith M-L, Bastos AD, Etter EMC, Beltrán-Alcrudo D. Epidemiology of African swine fever in Africa today: sylvatic cycle versus socio-economic imperatives. Transbound Emerg Dis. 2019. https://doi.org/10.1111/ tbed.13117.

Phologane SB, Bastos ADS, Penrith M-L. Intra- and inter-genotypic size variation in the central variable region of the $9 R L$ open reading frame of diverse African swine fever viruses. Virus Genes. 2005. https://doi. org/10.1007/s11262-005-3254-z.
Pikalo J, Schoder ME, Sehl J, Breithaupt A, Tignon M, Cay AB, et al. The African swine fever isolate Belgium 2018/1 shows high virulence in European wild boar. Transbound Emerg Dis. 2020. https://doi.org/10.1111/ tbed.13503.

Plowright W, Thomson GR, Neser JA. African swine fever. In: Coetzer JAW, Thomson GR, Tustin RC, editors. Infectious disease of livestock, with special reference to southern Africa, vol. 1. Cape Town: Oxford University Press; 1994. p. 568-99.

Quembo CJ, Jori F, Heath L, Pérez-Sánchez R, Vosloo W. Investigation into the epidemiology of African swine fever virus at the wildlife-domestic interface of the Gorongosa National Park, central Mozambique. Transbound Emerg Dis. 2016. https://doi.org/10.1111/tbed.12289.

Quembo CJ, Jori F, Vosloo W, Heath L. Genetic characterisation of African swine fever isolates from soft ticks at the wildlife/domestic interface in Mozambique and identification of a novel genotype. Transbound Emerg Dis. 2018. https://doi.org/10.1111/tbed.12700.

Rahimi P, Sohrabi A, Ashrafihelan J, Edalat R, Alamdari M, Masoudi M, et al. Emergence of African swine fever virus, Northwestern Iran. Emerg Infect Dis. 2010. https://doi.org/10.3201/eid1612.100378.

Randrianantoandro TN, Kono H, Kubota S. Knowledge and behaviour from an animal disease outbreak-evidence from an item count technique in a case of African swine fever in Madagascar. Prev Vet Med. 2015. https:// doi.org/10.1016/j.prevetmed.2014.12.016.

Rivera EM. African swine fever in the Dominican Republic. In: Wilkinson PJ, editor. African Swine Fever. EUR 8466 EN. Luxembourg: Commission of the European Communities. 1983; p. 17-24.

Roger F, Crucière C, Randriamahefa N, Zeller H, Uilenberg G, Randriamparany T, et al. African swine fever in Madagascar: epidemiological assessment of the recent epizootic. Proceedings of the $9^{\text {th }}$ International Symposium on Veterinary Epidemiology and Economics. 2000; http://www.sciquest. org.nz/node/71049 Accessed 18 Jan 2018

Rousset D, Randriamparany T, Maharavo Rahantamalala CY, Randriamahefa $\mathrm{N}$, Zeller $\mathrm{H}$, Rakoto-Andrianarivelo $\mathrm{M}$, et al. Introduction de la peste porcine africaine à Madagascar, histoire et leçons d'une émergence. Arch Inst Pasteur Madagascar. 2001;67:31-3.

Rubira R. Disease control options for emergency animal diseases-necessary yet sensitive elimination of disease. Vet ital. 2007;43:333-48.

Saliki JT, Thiry E, Pastoret PP. La peste porcine africaine (African swine fever). Paris: Études et Synthèses de l'Institut d'Élevage et de Médecine Vétérinaire des Pays Tropicaux. 1985; No. 11.

Sánchez-Botija C. Peste porcina Africana. Nuevos desarrollos. Rev sci tech Off Int Epiz. 1982;1:991-1029.

Sánchez-Vizcaíno JM, Mur L, Basto ADS, Penrith ML. New insights into the role of ticks in Africa swine fever epidemiology. Rev sci tech Off int Epiz. 2015;34:503-11.

Sargsyan MA, Voskanyan HE, Karalova EM, Hakobyan LH, Karalyan ZA. Third wave of African swine fever in Armenia: virus demonstrates the reduction of pathogenicity. Vet World. 2018. https://doi.org/10.14202/vetwo rld.2018.5-9.

Sarr J, Diop M. Situation épizootiologique de la peste porcine africaine au Sénégal. Institut Sénégalais de Recherche Agricole, Laboratoire de I'Élevage et de Recherches Vétérinaires, Dakar, Senegal (unpublished report). 1990

Schulz K, Staubach C, Blome S, Viltrop A, Nurmoja I, Conraths FJ, et al. Analysis of Estonian surveillance in wild boar suggests a decline in the incidence of African swine fever. Sci Rep. 2019. https://doi.org/10.1038/s4159 8-019-44890-0

Schulz K, Staubach C, Blome S, Nurmoja I, Viltrop A, Conraths FJ, et al. How to demonstrate freedom from African swine fever in wild boar - Estonia as an example. Vaccines. 2020. https://doi.org/10.3390/vaccines8020336.

Simpson VR, Drager N. African swine fever antibody detection in warthogs. Vet Rec. 1979;105:61.

Simulundu E, Lubaba CH, van Heerden J, Kajihara M, Mataa L, Chambaro HM, et al. The epidemiology of African swine fever in "non-endemic" regions of Zambia (1989-2015): implications for disease prevention and control. Viruses. 2017. https://doi.org/10.3390/v9090236.

Smietanka K, Wózniakowski G, Kozak E, Niemczuk K, Fraczyk M, Bocian L, et al. African swine fever epidemic, Poland, 2014-2015. Emerg Infect Dis. 2016. https://doi.org/10.3201/eid2207.151708. 
Smith D, Cooper T, Pereira A, da Costa Jong JB. Counting the cost: the potential impact of African swine fever on smallholders in Timor-Leste. One Health. 2019. https://doi.org/10.1016/j.onehlt.2019.100109.

Steyn DG. Preliminary report on a South African virus disease amongst pigs. $13^{\text {th }}$ and $14^{\text {th }}$ Reports of the Director of Veterinary Education and Research, Union of South Africa. Pretoria: Government Printers. 1928; p. 415-428.

Steyn DG. East African virus disease in pigs. $18^{\text {th }}$ Report of the Director of Veterinary Services and Animal Industry, Union of South Africa 1 Pretoria: Government Printers. 1932; p. 99-109.

Swanepoel M, Leslie AJ, Hoffman LC. Farmers' perceptions of the extra-limital common warthog in the Northern Cape and Free State Provinces, South Africa. Wildlife Society Bulletin (2011-), 2016;40:112-121. https:// www.jstore.org/stable/10.2307/wildsocibull2011.40.1.112. Accessed 18 Mar 2020.

Taylor WP, Best JR, Couquhoun IR. Absence of African swine fever from Nigerian warthogs. Bull Anim Health Prod Afr. 1977;25:196-7.

Terpstra C, Wensvoort G. African swine fever in the Netherlands. Tijdschr Dieregeneesk. 1986;111:389-92.

Thomas LF, Bishop RP, Onzere C, McIntosh MT, Lemire KA, de Glanville WA, et al. Evidence for the presence of African swine fever virus in an endemic region of Western Kenya in the absence of any reported outbreak. BMC Vet Res. 2016. https://doi.org/10.1186/s12917-016-0830-5.

Trape J-F, Diatta G, Arnathau C, Bitam I, Sarih M, Belghyti D, et al. The epidemiology and geographic distribution of relapsing fever borreliosis in West and North Africa, with a review of the Ornithodoros erraticus complex (Acari: Ixodida). PLoS ONE. 2013. https://doi.org/10.1371/journ al.pone.0078473.

Tummeleht L, Jürison M, Kurina O, Kirik H, Jeremejeva J, Viltrop A. Diversity of Diptera species in Estonian pig farms. Vet Sci. 2020. https://doi. org/10.3390/vetsci7010013.

Turnbull DO. Nyasaland. Swine fever. Annual Report of the Veterinary Department, 1931. London: His Majesty's Stationery Office. 1932.

Turnbull DO. Nyasaland. Swine fever. Annual Report of the Veterinary Department, 1932. London: His Majesty's Stationery Office. 1933.

Turnbull DO. Nyasaland. Swine fever. Annual Report of the Veterinary Department, 1934. London: His Majesty's Stationery Office. 1934

Uilenberg G, Estrada-Peña A, Thal J. Ticks of the Central African Republic. Exp Appl Acarol. 2013. https://doi.org/10.1007/s10493-012-9605-2.

van Heerden J, Malan K, Gadaga BM, Spargo RE. Reemergence of African swine fever in Zimbabwe, 2015. Emerg Infect Dis. 2017. https://doi. org/10.3201/eid.2305.161238.

Vepkhvadze NG, Menteshashvili I, Kokhreidze M, Goginashvili K, Tigilauri T, Mamisashvili E, et al. Active surveillance of African swine fever in domestic swine herds in Georgia, 2014. Rev sci tech Off int Epiz. 2017;36(3):879-87.

Vergne T, Chen-Fu C, Li S, Capelle J, Edwards J, Martin V, et al. Pig empire under infectious threat: risk of African swine fever introduction into the People's Republic of China. Vet Rec. 2017. https://doi.org/10.1136/ vr.103950.

Vial L, Wieland B, Jori F, Etter E, Dixon L, Roger F. African swine fever virus in soft ticks. Senegal. Emerg Infect Dis. 2007. https://doi.org/10.3201/eid13 12.071022.
Vigário JD, Castro Portugal FL, Festas MB, Vasco SG. The present state of African swine fever in Portugal. In: Wilkinson PJ, editor. African Swine Fever. EUR 8466 EN. Luxembourg: Commission of the European Communities. 1983; p. 11-6.

Wadoum RE, Lichoti JK, Nantima N, Austine B, Amara L, Sesay AK, et al. Quantitative outcomes of a One Health approach to investigate the first outbreak of African swine fever in the Republic of Sierra Leone. Glob J Med Re: K Interdisciplinary, 2020;20:Version 1,0 Year 2020.

Wang T, Sun Y, Qiu H-J. African swine fever: an unprecedented disaster and challenge to China. Infect Dis Poverty. 2018. https://doi.org/10.1186/ s40249-018-0495-3.

Wang S-F, Wang W-H, Ishcol MRC, Lin C-Y. African swine fever: an emerging threat to Asian countries (editorial). J Exp Clin Microbiol. 2019a;2:14-5.

Wang W-H, Lin C-Y, Chang Ishcol MR, Urbina AM, Assavalapsakul W, Thitithanyanont $A$, et al. Detection of African swine fever in pork products brought to Taiwan by travellers. Emerg Microbes Infect. 2019b. https:// doi.org/10.1080/22221751.2019.1636615.

Wesley RD, Tuthill AE. Genome relatedness among African swine fever field isolates by restriction endonuclease analysis. Prev Vet Med. 1984;2:53-62.

Wilkinson PJ, Donaldson Al, Greig A, Bruce W. Transmission studies with African swine fever virus Infection of pigs by airborne virus. J Comp Path. 1977:87:487-95.

Wilkinson PJ, Lawman MJ, Johnston RS. African swine fever in Malta, 1978. Vet Rec. 1980;106:94-7.

Wilkinson PJ, Pegram RG, Berry BD, Lemche J, Schels HF. The distribution of African swine fever virus isolated from Ornithodoros moubata in Zambia. Epidemiol Infect. 1988;101:547-64.

Zani L, Masiulis M, Bušauskas P, Dietze K, Pridotkas G, Globig A, et al. African swine fever virus survival in buried wild boar carcasses. 2020. https:// doi.org/10.1111/tbed.13554 (In press)

Zani L, Forth JH, Forth L, Nurmoja I, Leidenberger S, Henke J, et al. Deletion at the $5^{\prime}$-end of Estonian ASFV strains associated with an attenuated phenotype. Sci Rep. 2018. https://doi.org/10.1038/s41598-018-24740-1.

Zani L, Dietze K, Dimova Z, Forth JH, Denev D, Depner K, et al. African swine fever in a Bulgarian backyard farm — a case report. Vet Sci. 2019. https:// doi.org/10.3390/vetsci6040094.

Zhou X, Li N, Luo Y, Liu Y, Miao F, Chen T, et al. Emergence of African swine fever in China, 2018. Transbound Emerg Dis. 2018. https://doi. org/10.1111/tbed.12989.

Zhou L, Yu EYW, Wang S, Sun C. African swine fever epidemic in China. Vet Rec. 2019. https://doi.org/10.1136/vr.14026.

\section{Publisher's Note}

Springer Nature remains neutral with regard to jurisdictional claims in published maps and institutional affiliations.

Ready to submit your research? Choose BMC and benefit from

- fast, convenient online submission

- thorough peer review by experienced researchers in your field

- rapid publication on acceptance

- support for research data, including large and complex data types

- gold Open Access which fosters wider collaboration and increased citations

- maximum visibility for your research: over $100 \mathrm{M}$ website views per year

At BMC, research is always in progress.

Learn more biomedcentral.com/submissions 